\title{
Raman spectroscopy as a powerful tool to characterize ceria-based catalysts
}

\author{
Stéphane Loridant ${ }^{1, *}$ \\ ${ }^{1}$ Univ Lyon, Université Claude Bernard-Lyon 1, CNRS, IRCELYON-UMR 5256, 2 av. A. \\ Einstein, F-69626 Villeurbanne Cedex, France \\ * Corresponding Author: Ph. + 33 [0] 472445 334, Fax + 33 [0] 472445 399, E-mail: \\ stephane.loridant@ircelyon.univ-lyon1.fr
}




\begin{abstract}
A review. $\mathrm{CeO}_{2}$ is widely used and investigated as an oxide catalyst or support due to its unique redox property of oxygen storage and release. In this paper, the different opportunities offered by Raman spectroscopy for advanced characterization of ceria-based catalysts are reviewed: spectral modifications induced by nanocrystallinity, defects, doping and reduction, identification of supported molecular species, isolated atoms and nanoclusters, characterization of surface modes, hydroxyl groups, reaction intermediates such as peroxo and superoxo species. Finally, in situ/operando studies for environmental catalysis are summarized illustrating Raman spectroscopy as a powerful tool to characterize ceria-based catalysts.
\end{abstract}

Key Words: Raman spectroscopy, ceria, heterogeneous catalyst, nanomaterials, in situ, operando. 


\section{Introduction}

$\mathrm{CeO}_{2}$ is widely used as a catalyst or support component due to its unique redox property of oxygen storage and release [1]. Apart from its well-established application in three-way catalysis (TWC) [2], ceria is looming as a catalyst component for a wide range of catalytic applications [3] such as soot oxidation [4,5], $\mathrm{NH}_{3}-\mathrm{SCR}$ reactions [6,7], remediation of volatile organic compounds (VOCs) [8], removal of $\mathrm{CO}_{2}, \mathrm{SO}_{2}$ and $\mathrm{NOx}$ gases [9], hydrogen purification and production processes [10], conversion of $\mathrm{CO}_{2}$ [11], wet air oxidation [12] reforming of hydrocarbons and so on [1]. The shape and size modification, surface/face reconstruction, and faceting of ceria at the nanoscale level can offer an important tool to govern activity and stability in these reactions [13-18]. Furthermore, strong interaction between noble metals and ceria leads to their higher dispersion, electronic modifications and enhanced catalytic activity [19].

Raman spectroscopy is powerful for advanced structural characterization of heterogeneous catalysts all along their life cycle [20]. The different possibilities offered by this technique in the case of ceria-based catalysts are reviewed in this paper. In Part 2, Raman spectra of pure $\mathrm{CeO}_{2}$ are described depending on its structural state (single crystal, nanocrystallized, nanostructured, reduced state). Then, spectral modifications induced by doping (Part 3) and observed for ceria-zirconia solutions (Part 4.1) are discussed. Characterization of catalysts such as noble metal oxides and vanadium oxide lying over ceria-based support allows unique distinguishing of different molecular species, nanoclusters and crystalline phases. This is highlighted in Parts 4.2 and 5.1, respectively. Finally, a selection of in situ/operando studies are summarized in Parts 5.2 and 5.3 to illustrate the wide panel of Raman spectroscopy.

\section{Raman spectra of pure $\mathrm{CeO}_{2}$}

Raman spectroscopy provides identification of crystalline phases present in materials from the number of observed bands and their wavenumbers which are related to their space group and the bonds force constants, respectively. Usually, the Raman spectrum of a nanomaterial remains sufficiently similar to the corresponding single crystal one to allow univocal identification but as Raman spectroscopy is sensitive to the short-range order, to the chemical bond itself, spectral modifications (wavenumber, width, intensity) of disordered materials such as nanomaterials can be used to characterize them [21]. Therefore, Raman spectroscopy is widely used to characterize nanomaterials such as heterogeneous catalysts. In this part, spectral modifications observed for nanocrystallized $\mathrm{CeO}_{2}$ are discussed regards the spectrum 
of single crystal.

\subsection{Single crystal}

$\mathrm{CeO}_{2}$ crystallizes in the cubic fluorite structure corresponding to the space group $\mathrm{O}_{\mathrm{h}}{ }^{5}$ (Fm3m). Group theory predicts one triply degenerate Raman active optical phonon $\left(\mathrm{F}_{2 \mathrm{~g}}\right.$ symmetry) and one infrared-active optical phonon ( $\mathrm{F}_{1 \mathrm{u}}$ symmetry), which presents either LO or TO character (with different wavenumbers) depending on the relative propagation/polarization directions of the mode [22]. The $F_{2 g}$ band located at $466 \mathrm{~cm}^{-1}$ at room temperature is often attributed for simplicity to symmetrical stretching vibration of the $\mathrm{Ce}-\mathrm{O} 8$ units. In fact, it involves both $\mathrm{Ce}-\mathrm{O}$ and $\mathrm{O}-\mathrm{O}$ force constants, the $\mathrm{O}-\mathrm{O}$ contribution being larger than the Ce-O stretching one [23]. Furthermore, the main band is quite intense because of high symmetry of the $\mathrm{CeO}_{2}$ structure and of high polarizability of the $\mathrm{Ce}-\mathrm{O}$ bonds. Therefore, characterization of ceria-based materials by Raman spectroscopy is very suitable. Furthermore, a weak band around $1180 \mathrm{~cm}^{-1}$ corresponds to the overtone of the LO mode (Raman inactive) located at $595 \mathrm{~cm}^{-1}$ and is therefore labelled 2LO [22,24]. The TO mode is located at $272 \mathrm{~cm}^{-1}[22,24]$.

Other second-order features at 264, 366, 550,600,676, $935 \mathrm{~cm}^{-1}$ were assigned to phonon overtones from the $\mathrm{X}$ and $\mathrm{L}$ points on the Brillouin-zone boundary on the basis of selection rules and using a rigid-ion model to determine the phonon dispersion curves [24]. Such curves were also obtained from DFT calculations achieved on a $(4 \times 4 \times 4)$ primitive $\mathrm{CeO}_{2}$ cell without strain $[25,26]$ and as a function of positive and negative isotropic strain, which could be induced thermally or by cationic doping [25].

\subsection{Nanocrystalline $\mathrm{CeO}_{2}$}

As shown in Figure 1a, decreasing the crystallite size of $\mathrm{CeO}_{2}$ leads to broadening, asymmetry and red-shift of the $F_{2 g}$ band mostly below $50 \mathrm{~nm}$ [27-29]. Its half-width was shown to vary linearly with the inverse of crystallite size [28,29]. Broadening and asymmetry is due to reduction of the phonon lifetime according to the Phonon Confinement Model (PCM) [21,28-32]. The presence of defects also contributes to broadening [21,27-29,33] while the red-shift can be explained by strains due to the high curvature of nanocrystallites [27-29] and surface relaxation [34]. The lattice disorder was analysed from the shape of the Raman line using a spatial correlation model and calculating the phonon correlation length [21,28,29]. Typically, it was $10 \mathrm{~nm}$ for crystallites larger than $100 \mathrm{~nm}$ and decreased sharply below to reach $1 \mathrm{~nm}$ for crystallites of $4 \mathrm{~nm}$ (Figure 1b). Such large change in correlation 
length was attributed to grain boundaries whose volume increases decreasing the crystallite size $[21,28,29]$.

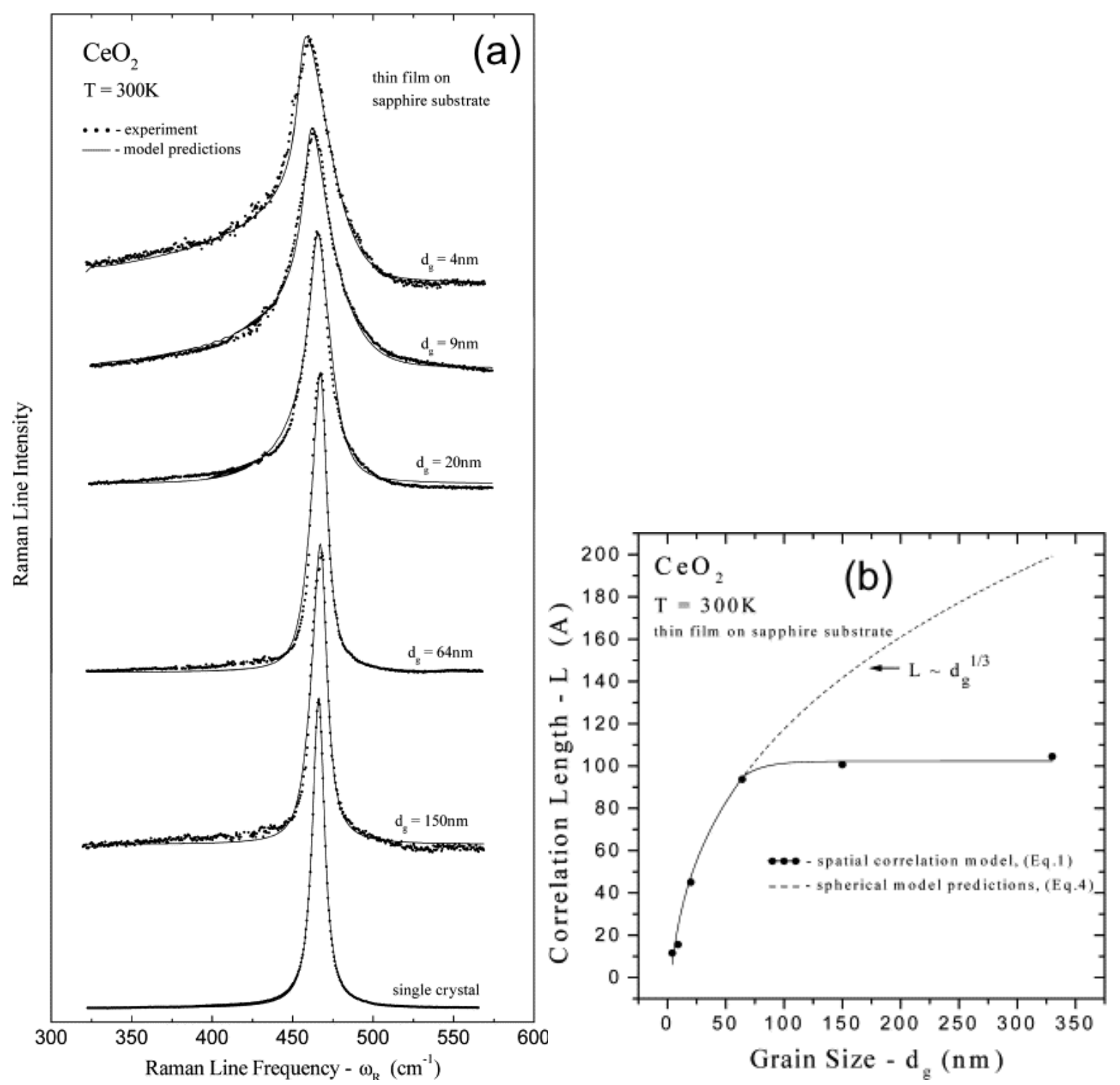

Figure 1. (a) Raman spectra of single crystal and nanocrystalline $\mathrm{CeO}_{2}$ together with the curve fit according to the spatial correlation model (b) Correlation length as a function of crystallite size of nanocrystalline $\mathrm{CeO}_{2}$ thin films. The dashed line is the correlation length estimated from a spherical model [28].

The temperature dependence of the $F_{2 g}$ Raman mode phonon wavenumber and broadening in $\mathrm{CeO}_{2}$ nanocrystals was studied [35]. The phonon softening and phonon bandwidth were calculated using a model which considers the three-and four-phonon anharmonic processes. Note that an increase in the laser power leads to the same spectral evolutions by heating effect [36]. Furthermore, a reversible cubic (Fm-3m) to tetragonal (P42/nmc) phase transition was reported for nanosized $(5-18 \mathrm{~nm})$ ceria decreasing the 
temperature from 75 to $-25{ }^{\circ} \mathrm{C}$ while the lattice parameter was increased [37]. The electronic structures of these two phases are different: residual electrons are trapped in the oxygen vacancies for the tetragonal one whereas they occupy $\mathrm{Ce} f$ orbitals (presence of $\mathrm{Ce}^{3+}$ cations) for the cubic one. It led to observation of an additional band at $276 \mathrm{~cm}^{-1}$ which was attributed to the opposite vibrations of $\mathrm{Ce}$ and $\mathrm{O}$ atoms along c-axis which is Raman silent for the fluorite structure [37].

The broad band around 550-600 $\mathrm{cm}^{-1}$ observed in nanocrystallites is called the Dband' (D as Defects). Its location fits with second-order features $\left(2 \mathrm{TO}\left(600 \mathrm{~cm}^{-1}\right)\right.$ or 2LA $\left(550 \mathrm{~cm}^{-1}\right)$ mode) according to the Weber's study [24] but such attribution has to be ruled out since it cannot explain its specific enhancement for nanocrystallites. Alternatively, it was attributed to the LO mode ( $\mathrm{F}_{1 \mathrm{u}}$ symmetry, Raman inactive) arising from relaxation of selection rules $[37,38]$ due to symmetry lowering induced by the presence of defects. Note that such defects could be Frenkel-type oxygen defects which were shown to be present in nanocrystalline $\mathrm{CeO}_{2}[39,40]$ : an oxygen atom is then displaced from its lattice position to an interstitial site. Recently, DFT calculations on $(2 \times 2 \times 2)$ cubic supercell containing 96 atoms $\left(\mathrm{Ce}_{32} \mathrm{O}_{64}\right)$ with one $\mathrm{V}_{\mathrm{O}} \ddot{ }$ oxygen vacancy $\left(\mathrm{Ce}_{32} \mathrm{O}_{63}\right)$ were undertaken [26]: one Raman band (first order) was calculated at $500 \mathrm{~cm}^{-1}$ for $\mathrm{Ce}_{32} \mathrm{O}_{63}$ cluster containing $\mathrm{Ce}^{3+}$ in direct proximity to the $\mathrm{V}_{\mathrm{O}} \ddot{ }$ defect and another one at $480 \mathrm{~cm}^{-1}$ when $\mathrm{Ce}^{3+}$ is located in the second coordination sphere of this defect. Therefore, the $550 \mathrm{~cm}^{-1}$ region was assigned to the $\mathrm{Ce}^{3+} \mathrm{O}_{7} \mathrm{~V}_{\mathrm{O}}$ “ coordination, whereas the $525 \mathrm{~cm}^{-1}$ region was attributed to the $\mathrm{Ce}^{4+} \mathrm{O}_{7} \mathrm{~V}_{\mathrm{O}}$ " coordination [26]. Even if there is a significant shift between the calculated and the experimental values (the component near $600 \mathrm{~cm}^{-1}$ is not addressed) and even if Frenkel defects were not considered in this work, it should serve as reference in the future. Zhang

As illustrated by the comparison Raman spectra achieved at 514 and $364 \mathrm{~nm}$ in Figure $2 \mathrm{~b}$, the relative intensity of the D band is higher using ultraviolet (UV) excitation. In one hand, such feature can be interpreted by surface segregation of defects as UV excitation favours analysis of surface layers [42 and references therein]. As shown in Figure 2a, absorption due to the band gap of $\mathrm{CeO}_{2}$ is much higher at $364 \mathrm{~nm}$ than at $514 \mathrm{~nm}$. On the other hand, the high intensity of the $2 \mathrm{LO}\left(1180 \mathrm{~cm}^{-1}\right)$ and $3 \mathrm{LO}\left(1770 \mathrm{~cm}^{-1}\right)$ overtones was explained by resonance Raman effect which occurs when the wavelength of the laser exciting line is close to the one of an electronic transition [43] leading to multiphonon relaxation [42]. Hence, the D band could be enhanced either by a reduction of the penetration depth and a resonance effect using UV excitation.

UV Raman spectra achieved on nanoceria contained two D components at 590 and 
$560 \mathrm{~cm}^{-1}$. The latter one enhanced after reduction à $500{ }^{\circ} \mathrm{C}$ was attributed to defect containing oxygen vacancies in agreement with the assignment from DFT calculations (see above and ref [26]). Upon $\mathrm{O}_{2}$ consecutive adsorption at room temperature, the shoulder at 560 $\mathrm{cm}^{-1}$ disappears instantly and the D band shifts back to $590 \mathrm{~cm}^{-1}$ [39].
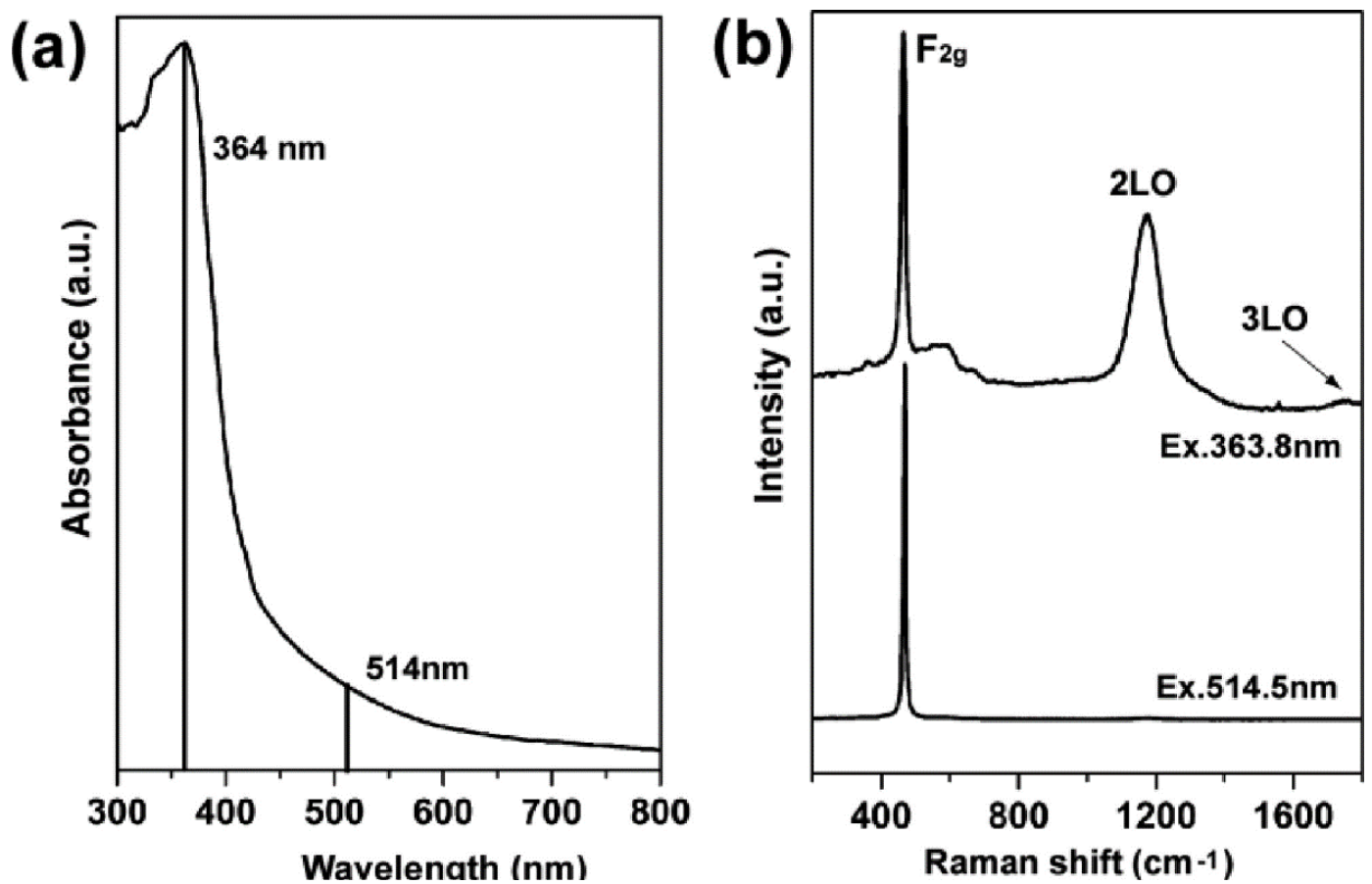

Figure 2. (a) Absorption spectrum and (b) UV/vis Raman spectra of ceria sample annealed at $1000{ }^{\circ} \mathrm{C}$ (crystallite size: $82.2 \mathrm{~nm}$ ). Reprinted with permission from [42] Copyright 2009 American Chemical Society.

Another weak band observed around $250-260 \mathrm{~cm}^{-1}$ has been reported in several studies on nanocrystallized $\mathrm{CeO}_{2}[39,44,45]$. A relatively intense second order 2TA mode can be found in this spectral range according to the density of vibrational states (2w-DOS) [24,26]. However, such assignment has to be ruled out because the relative intensity of the band around 250-260 $\mathrm{cm}^{-1}$ strongly increases for small $\mathrm{CeO}_{2}$ nanoparticles [26]. Convincingly, it was recently assigned from DFT calculations to a surface mode of the clean $\mathrm{CeO}_{2}$ (111) surface as well as a shoulder at 400-405 $\mathrm{cm}^{-1}$ [26,33]. The two bands evolve synchronously upon reduction and reoxidation [46]. The former corresponds to the $\mathrm{O}-\mathrm{Ce}$ longitudinal stretching of atoms in the outermost layers and the latter to a transversal $\mathrm{Ce}-\mathrm{O}$ stretching vibration. It is worth mentioning that the two bands observed at 270 and $315 \mathrm{~cm}^{-1}$ for $\mathrm{CeO}_{2}$ nanofilms were previously attributed to surface modes [47].

\subsection{Nanostructured $\mathrm{CeO}_{2}$}

Raman spectra of various nanostructured $\mathrm{CeO}_{2}$ were compared in several studies $[39,48,49]$. Their overall shape was similar but the $F_{2 g}$ band was broader and redshifted for nanorods compared to nanocubes and nanooctahedra in line with lower crystallinity. 
Furthermore, the $\mathrm{I}_{\mathrm{D}} / \mathrm{I}_{\mathrm{F} 2 \mathrm{~g}}$ ratio was higher for nanorods indicating higher proportion of defects $[48,50]$. Defect chemistry of nanoshaped ceria was investigated by UV Raman through the evolution of the D band under $\mathrm{CO}, \mathrm{H}_{2} \mathrm{O}$ and methanol. Oxygen vacancy $\left(\mathrm{V}_{\mathrm{O}} \ddot{*}\right)$ defects were formed in $\mathrm{CO}$ at the expense of existing anion-Frenkel pair $\left(\mathrm{O}_{\mathrm{i}}{ }^{\prime \prime}\right)$ defects on cubes, whereas both defect types $\left(\mathrm{V}_{\mathrm{O}}{ }^{\circ}\right.$ and $\left.\mathrm{O}_{\mathrm{i}}{ }^{\prime \prime}\right)$ form on octahedra and rods [40]. Interestingly, the UV Raman spectra reported in this study contained shoulders at 404 and $487 \mathrm{~cm}^{-1}$ on both sides of the $F_{2 g}$ band which were explained by distortions in the fluorite structure.

\subsection{Reduced $\mathrm{CeO}_{2}$}

Reduction of $\mathrm{CeO}_{2}$ leads to formation of oxygen vacancies and $\mathrm{Ce}^{3+}$ cations (one for two). It leads to increase in the unit cell parameter, decrease in the bonds force constants leading to red-shift of the $\mathrm{F}_{2 \mathrm{~g}}$ band. An example is provided in Part 5.3 (see Figure 11 and related comments). Oxygen vacancies formation can be followed by a red-shift of the D band due to an increase in the relative intensity of the component at $550 \mathrm{~cm}^{-1}$ compared to the one at $590 \mathrm{~cm}^{-1}$ [40,51]. At high reduction rate, $\mathrm{Ce}_{2} \mathrm{O}_{3}$ can be formed leading to observation of bands near 409, 189 and $103 \mathrm{~cm}^{-1}$ [26,52].

Furthermore, the presence of $\mathrm{Ce}^{3+}$ cations present in $\mathrm{CeO}_{2}$ lattice can be evidenced using their electronic Raman scattering at $2100-2150 \mathrm{~cm}^{-1}$ associated to ${ }^{2} \mathrm{~F}_{5 / 2}=>{ }^{2} \mathrm{~F}_{7 / 2}$ transition via a virtual state [46,53-55]. The direct transition can be observed by IR spectroscopy [53]. The $\mathrm{Ce}^{3+}$ Raman electronic spectrum depends on the crystal field which is different for $\mathrm{Ce}_{2} \mathrm{Zr}_{2} \mathrm{O}_{7}$ pyrochlore, for instance: in this case, four bands are observed at 2147, 2492, 2556 and 2757 $\mathrm{cm}^{-1}[56]$.

Figure 3 compares the Raman spectra of Raman spectra of $\mathrm{Pt} / \mathrm{CeO}_{2}$ catalysts recorded in the $1900-2400 \mathrm{~cm}^{-1}$ spectral range upon redox sequences at $250{ }^{\circ} \mathrm{C}$. The band typical of $\mathrm{Ce}^{3+}$ at $2130 \mathrm{~cm}^{-1}$ was observed only after the reduction steps for which the proportion of $\mathrm{Ce}^{3+}$ deduced from TPR measurements was $20 \%$ [46]. 


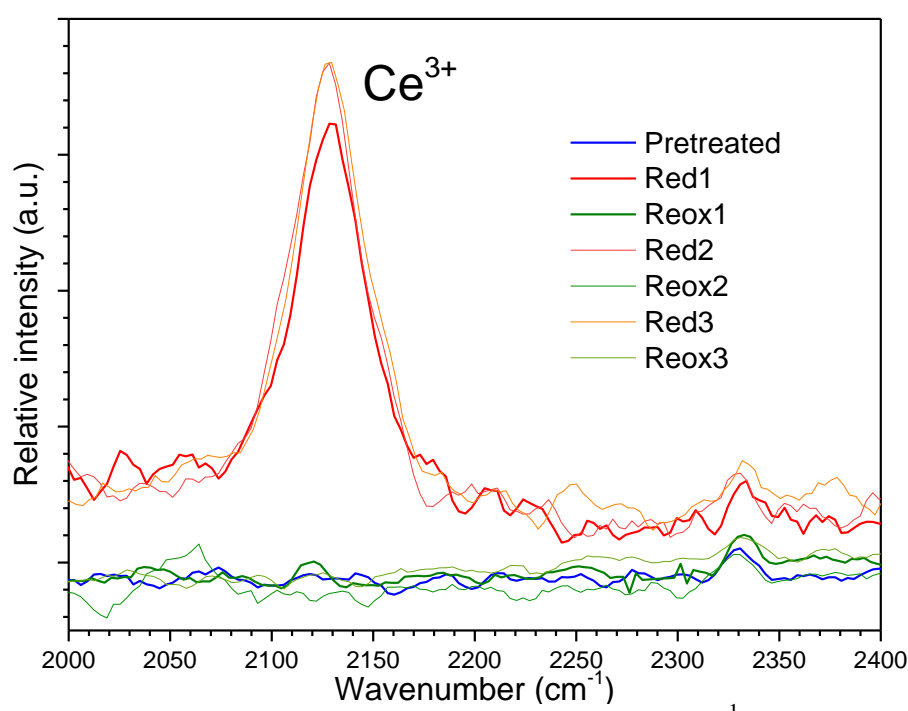

Figure 3. Raman spectra of $\mathrm{Pt} / \mathrm{CeO}_{2}$ catalysts recorded in the $1900-2400 \mathrm{~cm}^{-1}$ spectral ranges at RT after the initial oxidizing pre-treatment at $500{ }^{\circ} \mathrm{C}$ under $20 \% \mathrm{O}_{2}$ flow for $1 \mathrm{~h}$ and after successive reductions (Red 1,2 and 3) at $250{ }^{\circ} \mathrm{C}$ in $\mathrm{H}_{2}-\mathrm{N}_{2}$ and re-oxidations (Reox1, 2 and 3) at $250{ }^{\circ} \mathrm{C}$ in $\mathrm{O}_{2}-\mathrm{He}$.

\section{$2.5 \mathrm{OH}$ groups}

As by IR spectroscopy, the stretching vibrations of bridging and terminal $\mathrm{OH}$ surface groups of nanosized $\mathrm{CeO}_{2}$ can be distinguished by Raman spectroscopy [44,45,57-59] depending on the $v(\mathrm{O}-\mathrm{H})$ location. For instance, the band at $3716 \mathrm{~cm}^{-1}$ observed in Figure 4 is typical of terminal $\mathrm{OH}$ groups whereas the three ones at 3656,3669 and $3691 \mathrm{~cm}^{-1}$ were attributed to bridging $\mathrm{OH}$ groups [60].

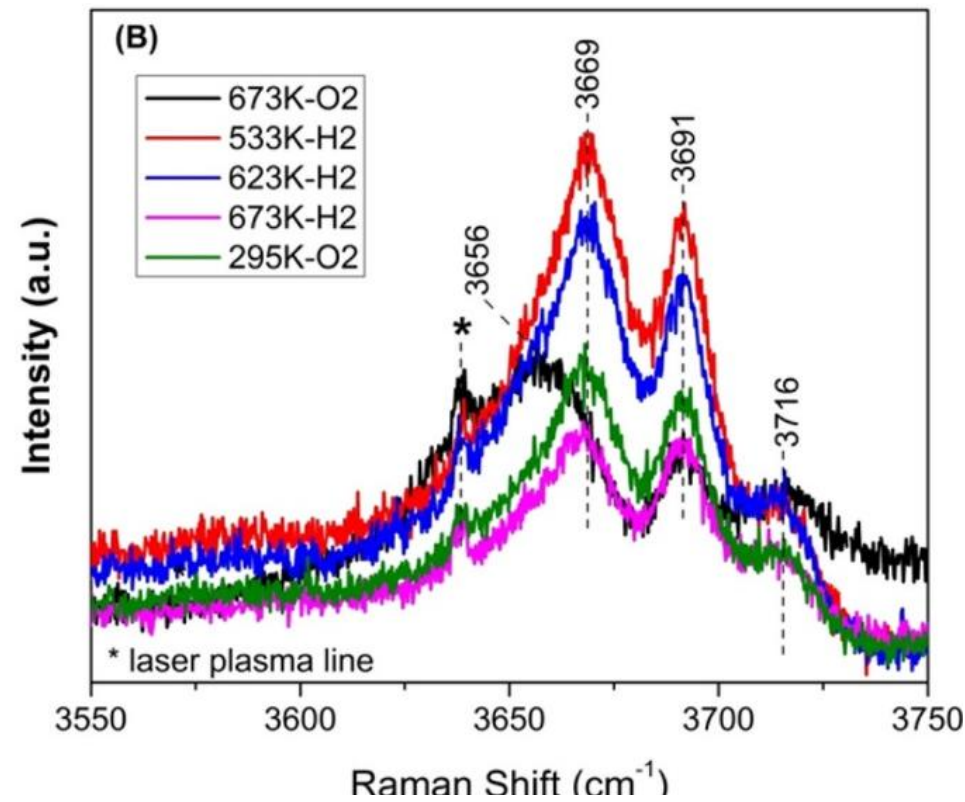

Figure 4. Raman spectra of $\mathrm{CeO}_{2}$ collected at room temperature after calcination at $673 \mathrm{~K}, \mathrm{H}_{2}$ treatment at 533, 623 , and $673 \mathrm{~K}$, and exposure to $\mathrm{O}_{2}$ at room temperature. The Raman peak marked with an asterisk (*) represents a laser plasma line and was used to normalize the Raman spectra intensity. Reprinted with permission from [60] Copyright 2017 American Chemical Society.

Upon $\mathrm{H}_{2}$ treatment, an increase in the relative intensity of the band at $3691 \mathrm{~cm}^{-1}$ as well 
as a blue shift of the bridging $\mathrm{OH}$ mode from 3656 to $3669 \mathrm{~cm}^{-1}$ with increased intensity revealed hydroxylation via $\mathrm{H}_{2}$ dissociation on the ceria surface (Figure 4). The decrease of their intensities above $623 \mathrm{~K}$ was due to the removal of $\mathrm{OH}$ groups via water formation, i.e., formation of oxygen vacancies [60].

\section{Doped ceria}

Doping corresponds to incorporation of other elements into the ceria crystalline structure. Cations with lower valence than IV are usually added to generate oxygen vacancies and improve oxygen anion conductivity $[1,4,5]$. In this part, spectral modifications induced by such doping are discussed.

\subsection{Characterization of the $D$ defect band}

The doping of fluorite $\mathrm{CeO}_{2}$ by lower valence cations can be easily evidenced through the shift of its $\mathrm{F}_{2 \mathrm{~g}}$ main band arising from modifications of $\mathrm{Ce}-\mathrm{O}$ force constants. Furthermore, the intensity of the $\mathrm{D}$ defect band at $550-600 \mathrm{~cm}^{-1}$ increases with the doping rate which was early attributed to $\mathrm{O}$ vacancies generated by the doping from a model calculation using a Green's function [61]. A clear correlation between its relative intensity and $\mathrm{P}\left(\mathrm{O}_{2}\right)$ was established upon annealing of $\mathrm{Ce}_{0.8} \mathrm{Sm}_{0.2} \mathrm{O}_{2-\delta}$ at $1000{ }^{\circ} \mathrm{C}$ [62]. In this work, two D components was distinguishable but not commented. Later, the D1 band located around $540-570 \mathrm{~cm}^{-1}$ whose relative intensity increases with the $\mathrm{RE}^{3+}$ rare earth doping rate has been assigned to extrinsic oxygen vacancies created into $\mathrm{CeO}_{2}$ in order to maintain charge neutrality. On the other hand, the D2 band near $600 \mathrm{~cm}^{-1}$ has been attributed to the intrinsic $\mathrm{V}_{\mathrm{O}}{ }^{\circ}$ oxygen vacancies present in $\mathrm{Ce}^{3+}-\mathrm{V}_{\mathrm{O}}$ " clusters because observed for pure nanocrystalline $\mathrm{CeO}_{2}$ [6366]. Corroboratively, the $I_{D 1} / I_{D 2}$ ratio was shown to increase with the dopant content [67]. However, one can wonder why vibrations of $\mathrm{Ce}^{3+}-\mathrm{V}_{\mathrm{O}}$ “ clusters would be blue-shifted of 50 $\mathrm{cm}^{-1}$ compared to $\mathrm{RE}^{3+}-\mathrm{V}_{\mathrm{O}}$ “ clusters. Furthermore, two components can be distinguished between 550 and $600 \mathrm{~cm}^{-1}$ for pure nanocrystalline $\mathrm{CeO}_{2}$ (see Part 2.2).

According to Nakajima et al. [68], the D1 band can be assigned to defect species including an oxygen vacancy that breaks the Oh symmetry and the D2 band to $\mathrm{MO}_{8}$-type defect species with Oh symmetry including a dopant cation without any oxygen vacancy, respectively. Hence, the D1 and D2 bands were attributed to vibrations of clusters containing two $\mathrm{Gd}^{3+}$ cations and one oxygen vacancy and to $\mathrm{GdO}_{8}$-type clusters without any oxygen vacancy, respectively [42]. These attributions of the D1 and D2 bands were later generalized for $\mathrm{Ce}_{1}$ ${ }_{x} \mathrm{M}_{\mathrm{x}} \mathrm{O}_{2-\delta}$ solid solutions ( $\mathrm{M}=\mathrm{Gd}, \mathrm{Zr}$, La, Sm, Y, Lu, and Pr) [69,70]. Note that one band near 
$600 \mathrm{~cm}^{-1}$ was observed for both $\mathrm{M}^{4+}(\mathrm{Zr})$ and $\mathrm{M}^{3+}$ (other elements) cations and was attributed in both cases to D2 defects [69]. In this study, dopants surface enrichment was evidenced comparing spectra recorded using 325 and $514 \mathrm{~nm}$ exciting lines [69]. More recently, the D1 and D2 bands were assigned on the basis of theoretical and experimental results, to stretching vibrations of $\mathrm{O}$ atoms between $\mathrm{M}^{3+}$ and $\mathrm{Ce}^{4+}$ ions near oxygen vacancy and to stretching vibrations of $\mathrm{O}$ atoms between $\mathrm{M}^{3+}$ or $\mathrm{M}^{4+}$ and $\mathrm{Ce}^{4+}$ ions without oxygen vacancy [71]. The attribution of the D1 band is in line with the one to $\mathrm{Ce}^{3+} \mathrm{O}_{7} \mathrm{~V}_{\mathrm{O}} \bullet \bullet$ coordination for undoped ceria (see Part 2.2 and [26]). However, the $\mathrm{Ce}^{3+} \mathrm{O}_{8}$ configuration was computed at lower

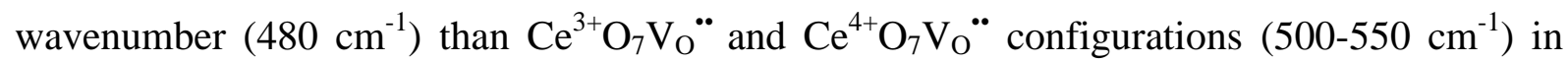
this study. Therefore, it appears that the attribution of the D2 band is still under debate.

Praseodymium doped ceria is a particular case since the relative intensity of the band at $570 \mathrm{~cm}^{-1}$ is high using a visible exciting line [64]. The observation of overtones and the fast change of relative intensity with excitation wavelength were explained by a resonance effect around $514 \mathrm{~nm}$, which involved a $\operatorname{Pr}^{4+}$ containing defect stabilized at the oxidized state leading to an absorption band around $530 \mathrm{~nm}$ [72]. This defects band overlaps with the D1 and D2 bands (Figure 5). The reduction of $\operatorname{Pr}^{4+}$ cations contained in such defects modifies the electronic properties of praseodymium doped ceria inhibiting the resonance effect and leads to observation of D1 and D2 defects (Figure 5). Additionally, the number of D1 defects that involved $\mathrm{Pr}^{3+}$ or $\mathrm{Ce}^{3+}$ cations and oxygen vacancies increases allowing them to be distinguished.

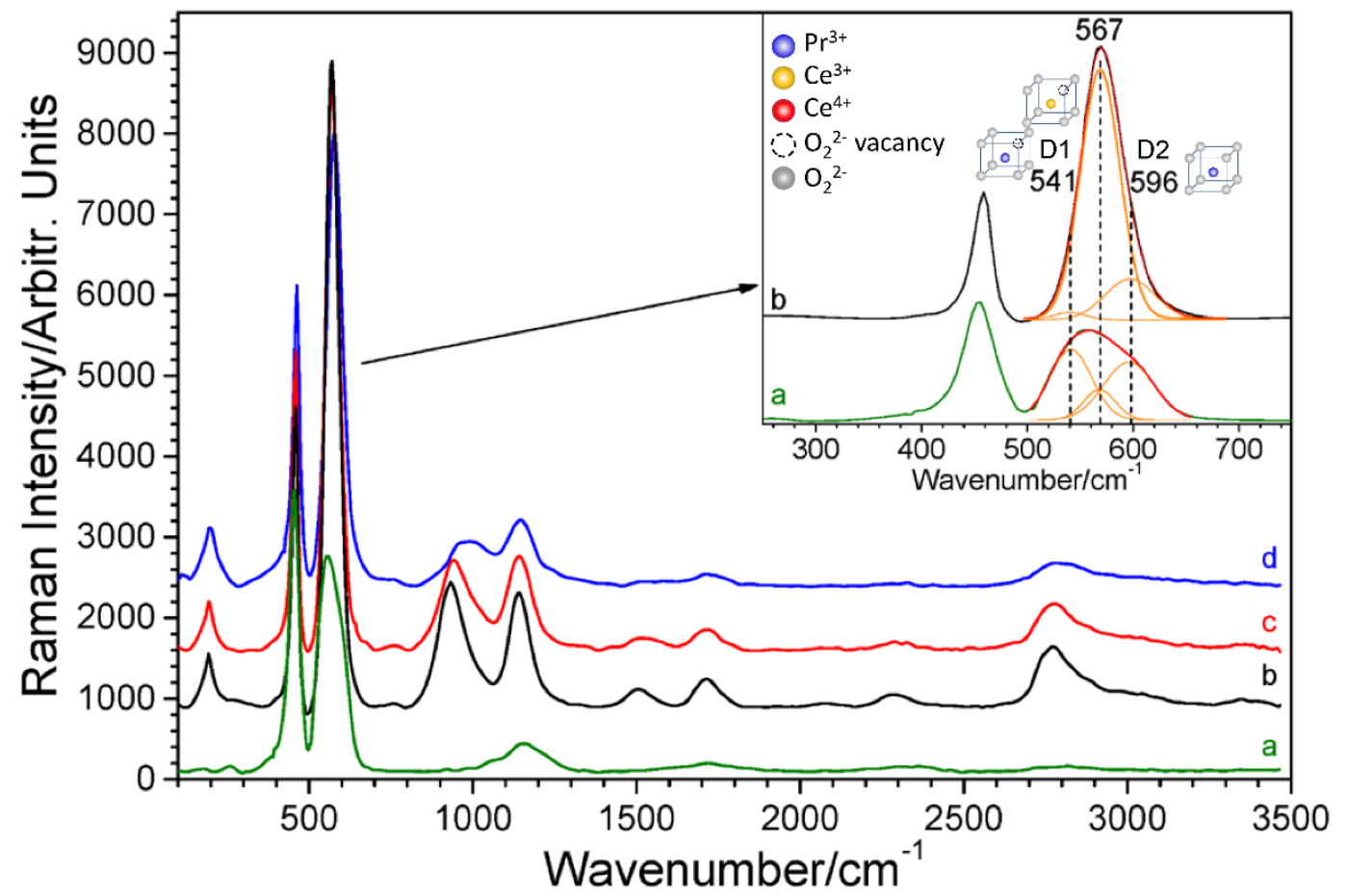

Figure 5. Raman spectra of $\mathrm{Ce}_{0.8} \mathrm{Pr}_{0.2} \mathrm{O}_{2-\delta}$ recorded after reduction at $800 \mathrm{~K}$ for 60 min under $10 \% \mathrm{H}_{2}$ flow at (a) 
$77 \mathrm{~K}$ and after oxidation at $800 \mathrm{~K}$ for 30 min under $5 \% \mathrm{O}_{2}$ flow (b) at $77 \mathrm{~K}$, (c) at $163 \mathrm{~K}$, and (d) at $298 \mathrm{~K}$ using $\lambda=514 \mathrm{~nm}$ and $\mathrm{P}=103 \mu \mathrm{W}$. The inset corresponds to a zoom of figures (a) and (b) between 300 and $700 \mathrm{~cm}^{-1}$ (adapted from [72]).

Finally, note that cerium is extracted from ores in which many other rare earth elements are present and the purification is not always very high. Hence, spectral features typical of doped ceria can be observed for undoped ceria containing rare earth impurities and the impurities level has to be considered when interpreting Raman spectra of undoped $\mathrm{CeO}_{2}$.

\subsection{Luminescence of rare earth dopants}

One major limitation of Raman spectroscopy is superimposition of fluorescence phenomena hiding Raman bands because of much higher intensity. However, in case of rare earth dopants, fluorescence bands which correspond to electronic transitions involving $4 \mathrm{f}$ levels are thin and provide additional information when their positions are different from the Raman ones. The two types of bands can be distinguished by changing the exciting line as the relative wavenumber of Raman bands does not shift contrarily to the luminescence ones [73]. As Raman spectrometer covers usually a broad spectral range (several hundreds of nanometers), different fluorescence bands can be observed to determine the symmetry of cationic sites as with a spectrofluorometer. Decay times can be measured using pulsed laser with synchronous detection.

\section{4. $\mathrm{CeO}_{2}$ as catalyst support}

As ceria-based support is nanocrystallized, all the features specific to nanocrystalline $\mathrm{CeO}_{2}$ (see part 2.2) are observed for catalyst supported on $\mathrm{CeO}_{2}$. Note that its cubic structure favours observation of vibrations of supported species especially because the single intense $\mathrm{F}_{2 \mathrm{~g}}$ band is located at relatively low wavenumber. Sintering upon thermal treatment can be evidenced from decrease in bandwidth. Chemical evolution of $\mathrm{CeO}_{2}$ support upon sulphidation is revealed from the $\mathrm{S}-\mathrm{O}$ and $\mathrm{S}=\mathrm{O}$ stretching vibrations observed in the $900-1400$

$\mathrm{cm}^{-1}$ spectral range allowing identification of various surface oxysulfur species and bulk cerium-oxysulfur species [74,75]. Formation of $\mathrm{CePO}_{4}$ in various phosphorus-contaminated automotive catalysts containing ceria as a washcoat component were observed using Raman spectroscopy [76]. UV Raman was particularly useful for detecting $\mathrm{CePO}_{4}$ in customer-aged samples showing large fluorescent backgrounds under visible excitation.

Ceria-zirconia solid solutions are widely used in gas exhaust catalysts because improved thermal stability while also improving oxygen anionic mobility $[1,2,4,5]$. Noble 
metals deposited on ceria-zirconia supports are widely used to catalyse oxidation and reduction reactions achieved in vehicle exhaust pipe for pollutants abatement. Therefore, Raman spectra of $\mathrm{CeO}_{2}-\mathrm{ZrO}_{2}$ solid solutions and supported noble metals are presented and discussed in the following.

\section{1 $\mathrm{CeO}_{2}-\mathrm{ZrO}_{2}$ system}

Raman spectroscopy has been also extensively used to distinguish polymorphs with subtle differences in $\mathrm{O}^{2-}$ atomic position in the $\mathrm{CeO}_{2}-\mathrm{ZrO}_{2}$ nano-oxide system [38,77-82]. The phase diagram of the $\mathrm{Ce}_{1-\mathrm{x}} \mathrm{Zr}_{\mathrm{x}} \mathrm{O}_{2-\mathrm{y}}$ mixed oxides is quite complex with three stable phases (monoclinic, tetragonal (t), and cubic) and two metastable tetragonal phases ( $t$ ', $\mathrm{t}^{\prime}$ '). The space group of the later phases is $\mathrm{P} 42 / \mathrm{nmc}$ with oxygen displacement in both cases while the c/a ratio is slightly higher than 1 for the t' phase and equal to 1 (pseudo cubic) for t" $[79,82]$. For large crystals (like in ceramics, for instance), the domain of stability at RT of t' ranges in the zirconium poor region (typically $15 \%<\mathrm{x}<30 \%$ ), the one of $\mathrm{t}^{\prime}$ in a broad region (typically $30 \%<x<85 \%)[79,82,83]$. The phase transitions with composition and temperature were studied by Raman spectroscopy for samples calcined at high temperature such as ceramics $[82,83]$. It was also shown that thermal "stability" of the metastable phases depends strongly on particle size [79,81]. In fact, symmetry increases as crystallite size decreases because of disordering.

Considering group theory, only one vibrational mode is Raman active for the cubic phase (space group Fm3m) while the six Raman active modes are active for the tetragonal phases (space group P42/nmc). All the characteristic bands of tetragonal phase were observed for the t' phase but the ones below $400 \mathrm{~cm}^{-1}$ were not observed for the t' phase in the case of large crystals $[81,82]$. Attribution to a given phase is harder for nanocrystallites because of bands broadening, activation of modes by zone folding and observation of defects modes (see part 2).

The evolutions of Raman spectra of $\mathrm{Ce}_{(1-\mathrm{x})} \mathrm{Zr}_{\mathrm{x}} \mathrm{O}_{2}$ solid solutions prepared by hydrothermal method followed by drying at $353 \mathrm{~K}$ overnight (as-prepared) and calcined at $1173 \mathrm{~K}$ for $4 \mathrm{~h}$ are plotted versus the $\mathrm{x}$ value in Figure 6a and b, respectively [84]. 

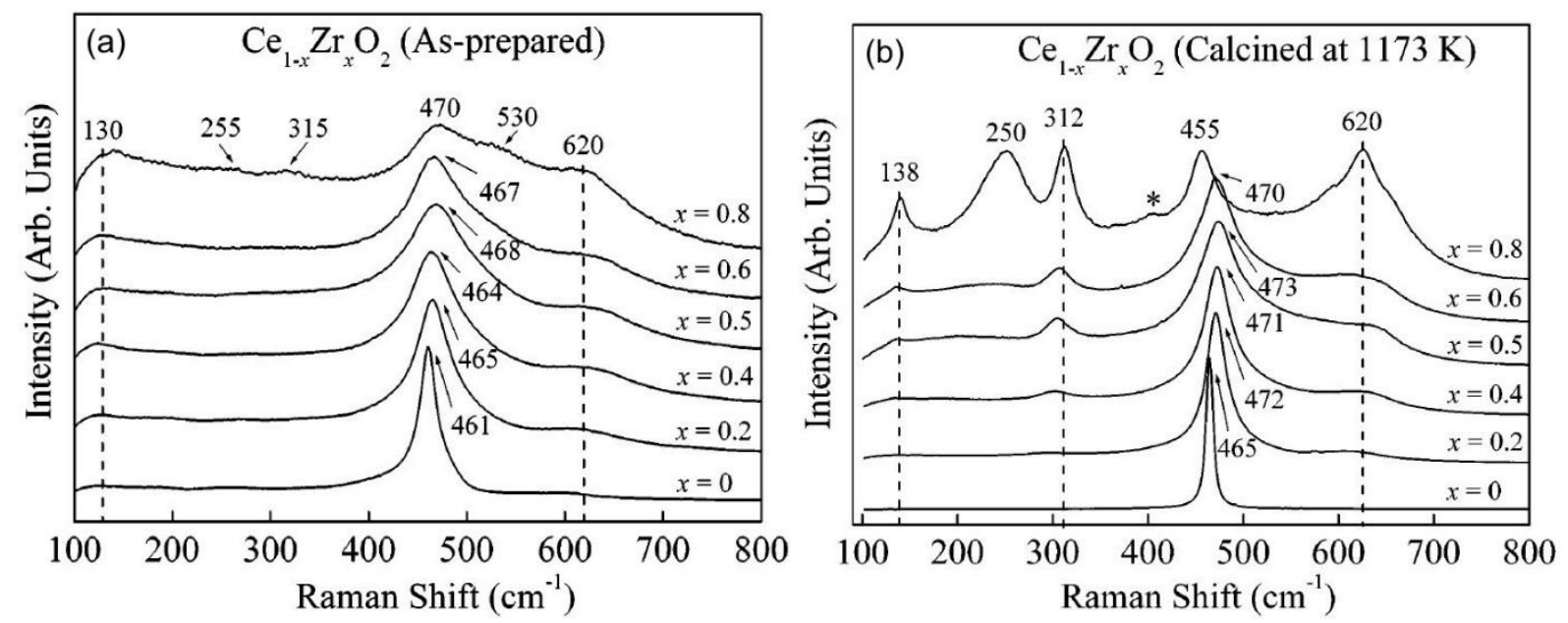

Figure 6. (a) Raman spectra of (a) as-prepared and (b) calcined at $1173 \mathrm{~K} \mathrm{Ce}_{(1-\mathrm{x})} \mathrm{Zr}_{\mathrm{x}} \mathrm{O}_{2}$ (x=0-0.8) samples. Reprinted with permission from [84] Copyright 2004 American Chemical Society.

Increasing the $\mathrm{x}$ value leads to a blue-shift (from 461 to $468 \mathrm{~cm}^{-1}$ for the as prepared samples and from 465 to $473 \mathrm{~cm}^{-1}$ for the calcined ones due to substitution of $\mathrm{Ce}^{4+}$ cations (ionic radius $0.97 \AA$ ) by smaller $\mathrm{Zr}^{4+}$ cations (ionic radius $0.84 \AA$ ) $[85,86]$. The associated band broadening reveals disorder induced by such substitution. The much larger width of the main band and its red-shift observed for the as prepared samples $(\mathrm{x}<0.8)$ indicates smaller crystallite size than for the calcined ones. Indeed, they ranged from 4.3 to $5.2 \mathrm{~nm}$ and from 14 to $48 \mathrm{~nm}$, respectively. After calcination at $1173 \mathrm{~K}$, no band was observed below $400 \mathrm{~cm}^{-1}$ for $\mathrm{x}=0.2$ in agreement with the presence of $\mathrm{t}$ " "phase according to the phase diagram whereas the bands of tetragonal t' phase were observed for $\mathrm{x}$ ranging from 0.4 to 0.8 . For the as prepared samples, no band was observed below $400 \mathrm{~cm}^{-1}$ for $\mathrm{x}<0.8$. It can be due to either the decrease of crystallite size of t' phase or to stabilization of $t$ " phase. These two explanations show clearly that Raman spectra of nanosized $\mathrm{Ce}_{1-\mathrm{x}} \mathrm{Zr}_{\mathrm{x}} \mathrm{O}_{2-\mathrm{y}}$ mixed oxides has to be interpreted with care.

However, combined visible (non-resonant) and UV (resonant) Raman spectra were very useful in studying the structural properties of $\mathrm{Ce}_{1-\mathrm{x}} \mathrm{Zr}_{\mathrm{x}} \mathrm{O}_{2}$ catalysis at the nanoscale because it provided detection selectivity in the tetragonal and cubic phases in $\mathrm{CeO}_{2}-\mathrm{ZrO}_{2}$ nanocrystals, respectively [87]. In particular, UV Raman spectra clearly evidenced the presence of a cubic phase containing $\mathrm{Ce}^{3+}$ cations in mixed oxide nanocrystals even in cases where they are characterized as the $t^{\prime}$ and 't' phase by XRD and visible-Raman spectroscopy. It was previously suggested from X-ray absorption spectra that the increase in the $\mathrm{Ce}^{3+}$ concentration with $\mathrm{Zr}^{4+}$ doping was due to larger ionic radius of $\mathrm{Ce}^{3+}(1.04 \AA)$ than both $\mathrm{Ce}^{4+}(0.97 \AA)$ and $\mathrm{Zr}^{4+}(0.84 \AA)$ leading to decrease the total lattice-strain energy that accumulated due to the large interval between the ionic radii of $\mathrm{Ce}^{4+}$ and $\mathrm{Zr}^{4+}$ [88]. The anionic sublattice structure of 
$\mathrm{Ce}_{1-\mathrm{x}} \mathrm{Zr}_{\mathrm{x}} \mathrm{O}_{2-\delta}$ solids was also shown to depend on the preparation route by Raman spectroscopy [87]: for $x=0.5$, the pseudo cubic $t^{\prime \prime}$ phase would be formed for the solid prepared by the citrate sol-gel method, while phase segregation (mixture of cubic, tetragonal phase) was proposed to occur for the corresponding material prepared by a coprecipitation with urea method [89]: a larger extent of defects and interstitial $\mathrm{O}$ atoms was evidenced for the materials prepared by the citrate sol-gel method. Furthermore, a novel approach based on sequential in situ Raman spectra under alternating oxidizing $\left(20 \% \mathrm{O}_{2} / \mathrm{He}\right)$ and reducing $(5 \%$ $\mathrm{H}_{2} / \mathrm{He}$ ) gas atmospheres showed that the D1 band above $600 \mathrm{~cm}^{-1}$ was selectively attenuated under reducing conditions at $450{ }^{\circ} \mathrm{C}$ for both undoped and rare earth doped solid solutions and was assigned to a metal-oxygen vibrational mode involving interstitial oxygen atoms that can be delivered under suitable conditions [89].

Finally, typical Raman spectra of $\kappa$ and $t^{*} \mathrm{CeZrO}_{4}$ obtained from $\mathrm{Ce}_{2} \mathrm{Zr}_{2} \mathrm{O}_{7+y}$ pyrochlore were also reported [90]: The spectrum of the $\kappa$ phase contains bands near 171, 274, 306, 437, $475,570,602,643 \mathrm{~cm}^{-1}$. Their relative intensities vary depending on the local oxygen atom arrangements. The spectrum of $\mathrm{t}^{*} \mathrm{CeZrO}_{4}$ is close to the one of the $\mathrm{t}^{\prime}$ phase implying that the unit cells of t' and $t^{*}$ were essentially the same [90].

\subsection{Supported noble metals}

Raman spectroscopy also provides unique characterization of Pt-group noble metal oxides widely used in automobile exhaust catalysts since it allows to distinguish the different oxides and polymorphs even when supported at low loading [91,92]. For instance, segregated $\mathrm{PdO}$ can be easily evidenced by Raman spectroscopy from its strong $\mathrm{B}_{1 \mathrm{~g}}$ mode at $650 \mathrm{~cm}^{-1}$ especially when using excitation near $514 \mathrm{~nm}$ leading to resonance effect [93,94]. Interestingly, difference of blue-shifts were explained by difference of strain due to encapsulation of $\mathrm{PdO}$ particles inside ceria-zirconia solid solutions [93].

Observation of a broad band around $700 \mathrm{~cm}^{-1}$ was early reported for noble metal oxides formed on $\mathrm{CeO}_{2}$. It does not correspond to any crystalline phase as observed for $\mathrm{Rh}_{\mathrm{x}} \mathrm{Ce}_{1-\mathrm{x}} \mathrm{O}_{2-\delta}$ solid solutions calcined at $800{ }^{\circ} \mathrm{C}$ for which the shoulder at $650 \mathrm{~cm}^{-1}$ was related to the $\mathrm{A}_{1 \mathrm{~g}}$ mode of $\alpha-\mathrm{Rh}_{2} \mathrm{O}_{3}$ [95]. In fact, it has been associated with the capacity of ceria to form isolated M-O groups with $\mathrm{Rh}$, Ir, $\mathrm{Pd}$ and $\mathrm{Pt}$ [95]. For $\mathrm{Pt} / \mathrm{CeO}_{2}$ and $\mathrm{Pt} / \mathrm{Al}_{2} \mathrm{O}_{3}-\mathrm{CeO}_{2}$, the two bands at 550 and $690 \mathrm{~cm}^{-1}$ were attributed to vibrations of bridging Pt-O-Ce groups at the $\mathrm{Pt} / \mathrm{CeO}_{2}$ interface [97]. They correspond to isolated $\mathrm{Pt}^{2+}$ cations (not a PtOx phase) in interaction with $\mathrm{CeO}_{2}$ [46] and can maintain up to ca $150{ }^{\circ} \mathrm{C}$ under reducing conditions [98]. 
As shown in Figure 7, the higher the calcination temperature of $2 \% \mathrm{Pt} / \mathrm{CeO}_{2}$ catalysts, the higher their disappearing temperature suggesting that Pt-O-Ce bond strength is stronger increasing the calcination temperature [99]. Their disappearing temperature was shown to depend on both the support $\left(\mathrm{Ce}_{0.7} \mathrm{Zr}_{0.3} \mathrm{O}_{2}\right.$ vs $\left.\mathrm{CeO}_{2}\right)$ and the state of Pt (thermally stable single atoms vs nanoparticles) [100]. Similarly, the band at $670 \mathrm{~cm}^{-1}$ observed for iridium-ceria nanopowders synthesized by solution combustion was assigned to $\mathrm{Ir}-\mathrm{O}-\mathrm{Ce}$ stretching vibrations [101]. Note that the study of $\mathrm{M}-\mathrm{O}-\mathrm{Ce}$ bonds is particularly relevant in heterogeneous catalysis since they can be involved in Strong Metal Support Interaction (SMSI), in reduction process involved in formation of metal particles, in oxidation during their redispersion or even in a catalytic elementary step [46,97-100].
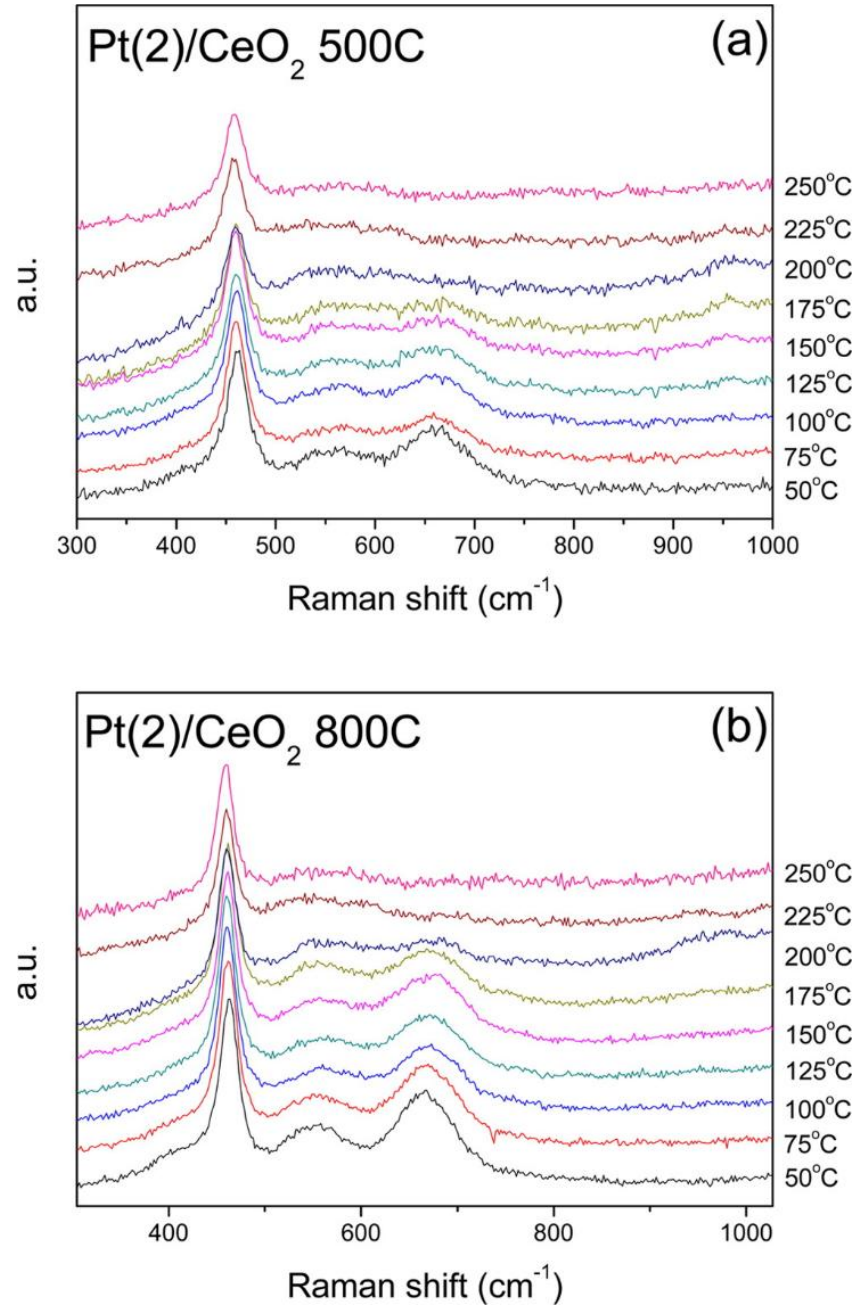

Figure 7. In situ Raman spectra of (a) $2 \mathrm{wt} \% \mathrm{Pt} / \mathrm{CeO}_{2}$ calcined at $500{ }^{\circ} \mathrm{C}$ (labelled $\mathrm{Pt}(2) / \mathrm{CeO}_{2} 500 \mathrm{C}$ ) and (b) 2 wt $\% \mathrm{Pt} / \mathrm{CeO}_{2}$ calcined at $800{ }^{\circ} \mathrm{C}$ (labelled $\mathrm{Pt}(2) / \mathrm{CeO}_{2} 800 \mathrm{C}$ ) recorded at temperature from 50 to $250{ }^{\circ} \mathrm{C}$ with a temperature step of $25{ }^{\circ} \mathrm{C}$, under $3 \% \mathrm{H}_{2} / \mathrm{Ar}$. The parentheses value is the wt $\%$ of $\mathrm{Pt}$ in the sample. Each temperature was maintained for $20 \mathrm{~min}$, and Raman spectra were obtained after cooling down to $50{ }^{\circ} \mathrm{C}$. Reprinted with permission from [99] Copyright 2004 American Chemical Society.

Significant red-shift and broadening of the $\mathrm{F}_{2 \mathrm{~g}}$ band of iridium-ceria [101] and nickelceria [102] catalysts synthesized by solution combustion and co-precipitation, respectively 
were previously reported. In the study on iridium-ceria [101], broadening due to confinement effect in nano-particles was ruled out since the crystallite size determined from XRD analysis did not vary significantly with the Ir content and was rather high $(30-50 \mathrm{~nm})$. However, the red-shift was associated with a larger lattice parameter determined by XRD evidencing Ir incorporation into $\mathrm{CeO}_{2}$ lattice and the broadening to disorder induced by this incorporation. Metal incorporation into the $\mathrm{CeO}_{2}$ lattice can also be revealed through additional bands: for instance, a band at $187 \mathrm{~cm}^{-1}$ was assigned to the $\mathrm{A}_{1}$ vibrations of $\mathrm{Pd}^{2+}$ ions in near square planar $\mathrm{PdO}_{4}$ subunits with the $\mathrm{C}_{4 \mathrm{v}}$ symmetry in the lattice of the $\mathrm{Pd}_{\mathrm{x}} \mathrm{Ce}_{1-\mathrm{x}} \mathrm{O}_{2-\mathrm{x}-\delta}$ solid solution [94]. Note that the band at $235-250 \mathrm{~cm}^{-1}$ observed in several of these studies [94,95,102] was tentatively attributed to the 2TA mode still according to the Weber's study (see part 2.2) [24].

\section{In situ/operando studies}

Raman spectroscopy is very valuable for in situ characterization of heterogeneous catalysts in gas and liquid phase. It is particularly true for reaction in aqueous phase since the Raman response of water is relatively weak by comparison with the IR one. Concerning gas phase reaction, the acquisition of Raman spectra up to typically $800{ }^{\circ} \mathrm{C}$ is possible using a green exciting line (most often used) because blackbody emission is low in the spectral range containing Raman bands [103]. Operando characterization corresponds to in situ spectra under true catalytic operation with on line activity measurements [104-112].

Raman scattering is an inherently low sensitivity process due to the small Raman cross-sections as compared to IR adsorption coefficients [113]. Therefore, Raman spectroscopy is most of the time used for structural characterization and observation of adsorbed species (intermediates or spectators) remains scarce compared to IR spectroscopy. When interpreting Raman spectra of ceria based catalysts, one should take into account the possible changes of absorption coefficient since ceria is a reductive oxide leading to UV-vis absorption and strong decrease in Raman bands intensity. An interesting wavelengthdependent absorption correction has been recently developped to take into account absorption effects [114].

In this part, a focus is made on in situ studies of vanadium oxide supported on $\mathrm{CeO}_{2}$, identification of peroxo and superoxo species and finally different works concerning environmental catalysis are summarized.

\section{1 vanadium oxide supported on $\mathrm{CeO}_{2}$}


As for numerous other supports, the effect of water vapour on the molecular structures of vanadium oxide supported on $\mathrm{CeO}_{2}$ was early investigated by I.E. Wachs et al. Two bands of molecular vanadates were observed at the dehydrated state around 1020-1030 and 900-920 $\mathrm{cm}^{-1}$ and assigned to $v(\mathrm{~V}=\mathrm{O})$ and $v(\mathrm{~V}-\mathrm{O}-\mathrm{V})$ stretching vibrations, respectively. The former is redshifted and broadened in the presence of water vapour because of hydrogen bonding between $\mathrm{V}=\mathrm{O}$ groups and $\mathrm{H}_{2} \mathrm{O}$ molecules [115]. In addition to structural information on molecular vanadates and determining the maximal coverage above which crystalline $\mathrm{V}_{2} \mathrm{O}_{5}$ is formed, Raman spectroscopy was used to follow $\mathrm{CeVO}_{4}$ formed by interaction between vanadates and ceria during thermal treatments and reactions [83,116-121]. In the case of ceria-zirconia supports, polyvanadates were shown to interact preferentially with the $\mathrm{CeO}_{2}$ portion of the mixed oxides and to form $\mathrm{CeVO}_{4}$ at high temperature [122]. Operando studies during oxidative dehydrogenation of ethane suggested that the $\mathrm{V}-\mathrm{O}-\mathrm{Ce}$ bonds must be the sites involved in the rate-determining step [123,124]. Finally, the vanadia structures on different nanoshaped ceria were identified by in situ visible $(633 \mathrm{~nm})$ and UV $(325 \mathrm{~nm})$ Raman spectroscopy as a function of loading and calcination temperature [117,125]. It was found that both the surface structure and the amount of defect sites play major roles in the $\mathrm{CeVO}_{4}$ formation. The easier formation of $\mathrm{CeVO}_{4}$ on ceria rods, compared with cubes or octahedra was attributed to their lowest surface oxygen vacancy formation energy and largest amount of defect sites. As shown in the visible spectra of dehydrated $\mathrm{VO}_{\mathrm{x}} / \mathrm{r}-\mathrm{CeO}_{2}\left(\mathrm{CeO}_{2}\right.$ nanorods) and $\mathrm{VOx} / \mathrm{c}-\mathrm{CeO}_{2}\left(\mathrm{CeO}_{2}\right.$ nanocubes $)$ samples plotted in Figures $8 \mathrm{~A}$, the surface vanadia evolves from monomeric to polymeric VOx and to $\mathrm{CeVO}_{4}$ crystalline phase as a function of VOx surface density. The main spectral differences between the two samples are the much weaker band of $\mathrm{CeVO}_{4}$ at high VOx surface density on $\mathrm{c}-\mathrm{CeO}_{2}$ and the absence of bands attributed to $\mathrm{V}_{2} \mathrm{O}_{5}$. The ratio of the $\mathrm{D}$ to $\mathrm{F}_{2 \mathrm{~g}}$ band $\left(\mathrm{I}_{\mathrm{D}} / \mathrm{I}_{\mathrm{F} 2 \mathrm{~g}}\right)$ obtained from the UV spectra and representative of the relative amount of defect sites in ceria, are plotted in the insets of Figures $8 \mathrm{~B}$ as a function of VOx surface density. It decreases continuously with increasing VOx loading for $\mathrm{r}-\mathrm{CeO}_{2}$ which implies that the surface VOx interacts closely with the defect sites in ceria rods. For $\mathrm{c}-\mathrm{CeO}_{2}$, the $\mathrm{I}_{\mathrm{D}} / \mathrm{I}_{\mathrm{F} 2 \mathrm{~g}}$ ratio seems rather insensitive to the change in surface VOx density. This was attributed to the much larger particle size of $c-\mathrm{CeO}_{2}$ than $\mathrm{r}$ $\mathrm{CeO}_{2}$. As Raman spectroscopy is a bulk technique, the $\mathrm{I}_{\mathrm{D}} / \mathrm{IF}_{2 \mathrm{~g}}$ seems unaffected by anchorage of $\mathrm{VOx}$ on $\mathrm{c}-\mathrm{CeO}_{2}$ even though the surface/subsurface defect sites are consumed by interactions with VOx species [125]. 

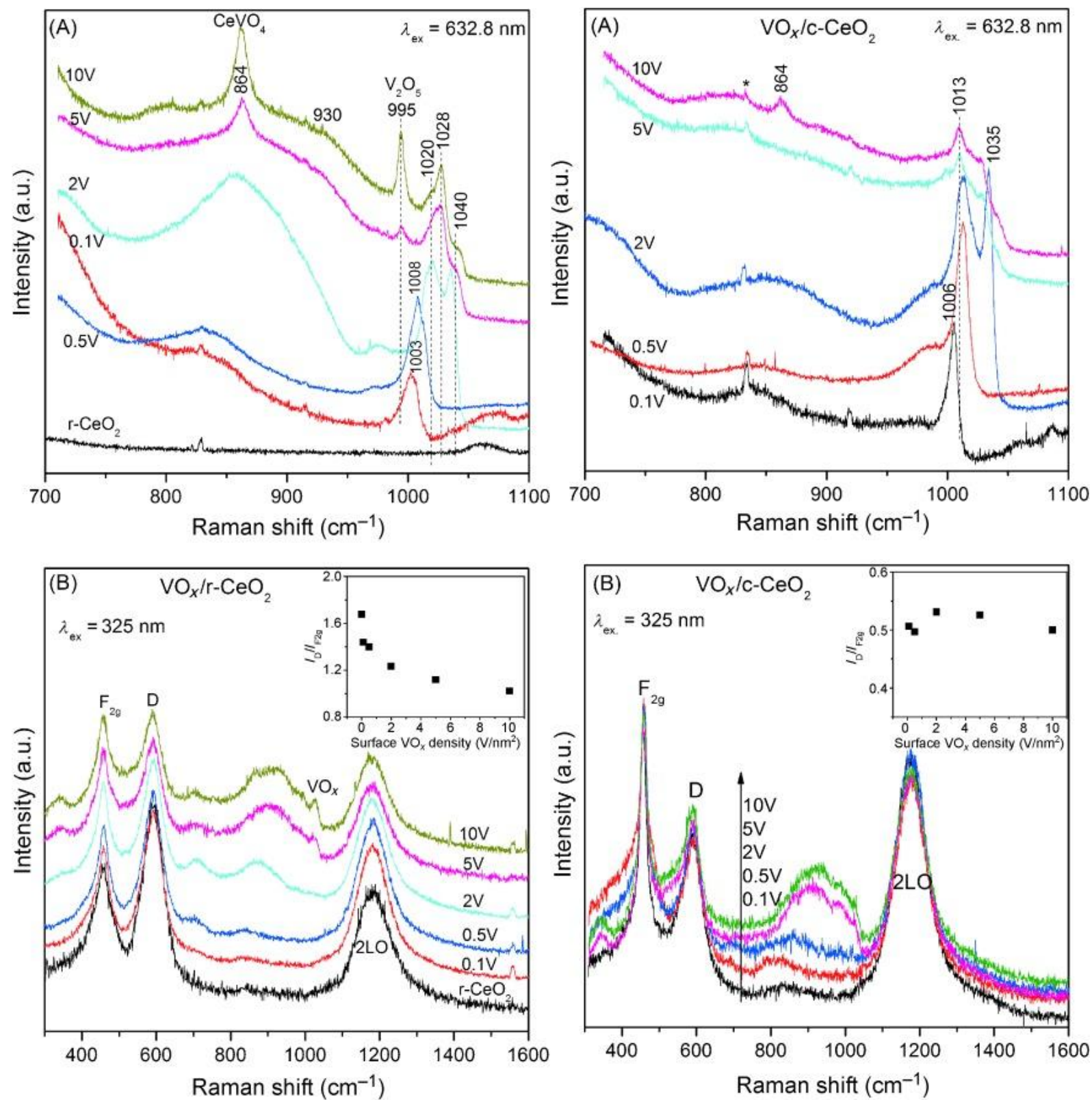

Figure 8. Visible (A) and UV (B) Raman spectra of dehydrated $\mathrm{VOx} / \mathrm{r}-\mathrm{CeO}_{2}\left(\mathrm{CeO}_{2}\right.$ nanorods) and $\mathrm{VOx} / \mathrm{c}-\mathrm{CeO} 2$ $\left(\mathrm{CeO}_{2}\right.$ nanocubes) samples as a function of surface VOx density $\left(\mathrm{V} \mathrm{nm}^{-2}\right)$. The inset in parts $\mathrm{B}$ is a plot of the ratio of $\mathrm{I}_{\mathrm{D}} / \mathrm{I}_{\mathrm{F} 2 \mathrm{~g}}$ versus the surface VOx density. * indicates a plasma line from the laser. Reprinted with permission from [125] Copyright 2012 Wiley-VCH Verlag GmbH\& Co. KGaA, Weinheim.

\subsection{Peroxo and superoxo species}

$\mathrm{O}_{2}{ }^{2-}$ peroxo and $\mathrm{O}_{2}^{-}$superoxo species are intermediates in the reoxidation sequence of reduced $\mathrm{CeO}_{2-\mathrm{x}}$ to $\mathrm{CeO}_{2}$ :

$$
\mathrm{O}_{2} \stackrel{e-}{\Rightarrow} \mathrm{O}_{2}^{-} \stackrel{e-}{\Rightarrow} O_{2}^{2-} \Rightarrow 2 O^{-} \stackrel{2 e-}{\Rightarrow} 2 O^{2-}
$$

Electrons consumed in this sequence are provided by $\mathrm{Ce}^{3+}$ cations leading to their reoxidation to $\mathrm{Ce}^{4+}$. Raman spectroscopy is sensitive to probe peroxo and superoxo species formed upon oxygen adsorption on reduced ceria $[39,44,45]$ because of the covalent character of their $\mathrm{O}=\mathrm{O}$ bonds. The $v(\mathrm{O}=\mathrm{O})$ stretching vibrations of peroxo and superoxo species are located in the 
800-900 $\mathrm{cm}^{-1}$ and 1100-1200 $\mathrm{cm}^{-1}$ spectral range, respectively. Chimisorption experiments have to be achieved at very low laser power under microscope to avoid formation of oxygen species by photolysis [44]. Figure 9 compares the Raman spectra of pristine $\mathrm{CeO}_{2}$ and $0.7 \%$ $\mathrm{Pt} / \mathrm{CeO}_{2}$ catalyst after reduction at 400,450 , and $500{ }^{\circ} \mathrm{C}$ recorded at low temperature $(-100$ ${ }^{\circ} \mathrm{C}$ ) under $\mathrm{O}_{2}$ flow. The three bands at $831-834 \mathrm{~cm}^{-1}, 854-862 \mathrm{~cm}^{-1}$ and $884-886 \mathrm{~cm}^{-1}$ correspond to $v(\mathrm{O}-\mathrm{O})$ of peroxo species adsorbed on three different sites: the higher its wavenumber (the stronger the bond force constant) is, the more labile is. This trend was confirmed by TPO experiments followed by Raman spectroscopy [44]. The distributions of peroxo species adsorbed on defect sites of $\mathrm{Pt} / \mathrm{CeO}_{2}$ and $\mathrm{CeO}_{2}$ were significantly different in spite of similar amounts: more labile species were formed during the reduction of $0.7 \%$ $\mathrm{Pt} / \mathrm{CeO}_{2}$ revealing that new sites were created during impregnation, calcination and/or reduction of $\mathrm{Pt} / \mathrm{CeO}_{2}$ compared to its bare support [44].
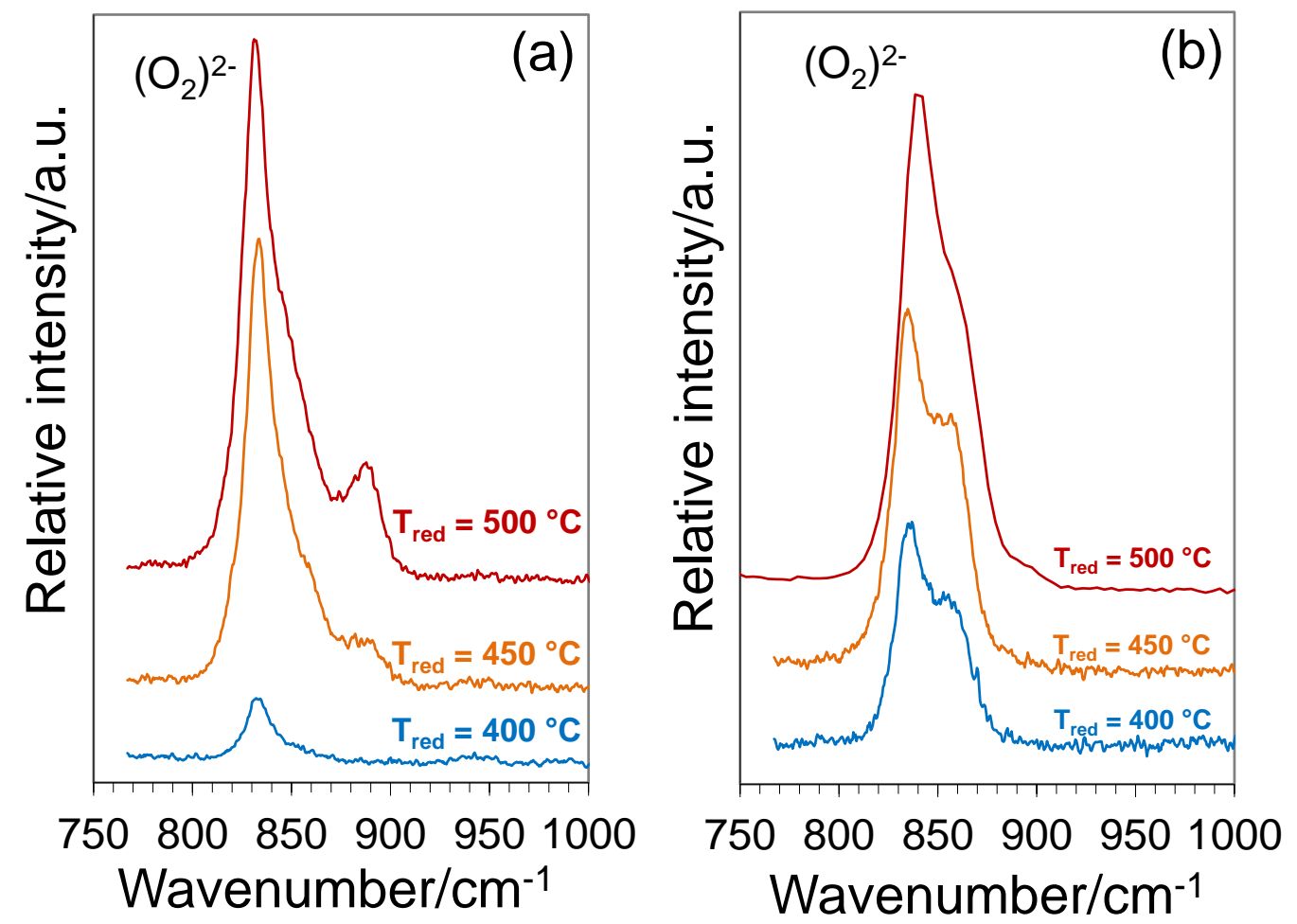

Figure 9. Comparison of the Raman spectra of pristine $\mathrm{CeO}_{2}$ and $0.7 \% \mathrm{Pt} / \mathrm{CeO}_{2}$ catalyst after reduction at 400 , 450 , and $500{ }^{\circ} \mathrm{C}$ recorded at $-100{ }^{\circ} \mathrm{C}$ under $\mathrm{O}_{2}$ flow.

Specific attribution to a given adsorption site has been sustained by DFT calculations [126129]. In particular, the shape-dependence of $\mathrm{O}_{2}$ adsorption and activation of ceria nanoparticles with (111) and (100) facets was investigated by in situ Raman spectroscopy and a facilitated formation of peroxide, superoxide, and weakly bound dioxygen species on the (100) facets was demonstrated [129]. 


\subsection{Environmental catalysis}

As peroxo and superoxo species are reoxidation intermediates (see part 6.2) as well as electrophilic species able to oxidize hydrocarbons, their observation by in situ and operando techniques is valuable when investigating environmental catalysis. For instance, consumption of peroxo species observed using operando Raman spectroscopy gave clear evidence for the participation of oxygen vacancies in $\mathrm{CO}$ oxidation over $\mathrm{Au} /$ ceria at room temperature [130]. In particular, two bands located at 847 and $881 \mathrm{~cm}^{-1}$ decreased during CO oxidation contrarily to the one at $830 \mathrm{~cm}^{-1}$. As no dynamic of the band at $847 \mathrm{~cm}^{-1}$ was observed for bare ceria, it was associated with defects in the vicinity of the $\mathrm{Au} / \mathrm{CeO}_{2}$ interface whereas the band at 881 $\mathrm{cm}^{-1}$ was attributed to peroxo species directly located at the gold-ceria interface. The evolution of peroxo species along redox sequences achieved on $\mathrm{Pt} / \mathrm{CeO}_{2}$ was related to stabilisation of subnanometric Pt rafts leading to an outstanding low temperature catalytic activity for $\mathrm{CO}$ oxidation [46]. The relative intensity of peroxo oxygen species was maximal after reoxidation at room temperature suggesting that their dissociation into $\mathrm{O}^{-}$and reduction to $\mathrm{O}^{2-}$ anions were limited at room temperature.

Operando Raman characterization of $\mathrm{OH}$ groups was particularly interesting in the study of the water-gas shift reaction over ceria-supported gold catalysts [131]. Indeed, the cleavage of $\mathrm{O}-\mathrm{H}$ bonds is considered to be a key step in both the redox and associative mechanisms proposed in the literature. In this study, ${ }^{18} \mathrm{O}$ labelling of bare $\mathrm{CeO}_{2}(111)$ and $\mathrm{Au} / \mathrm{CeO}_{2}(111)$ catalyst was achieved to gain insight into the mechanism of the WGS reaction, As shown in Figure 10, the hydroxyl bands at 3653 and $3682 \mathrm{~cm}^{-1}$ of bare $\mathrm{CeO}_{2}$ shift by -10 and $-12 \mathrm{~cm}^{-1}$, respectively under both $\mathrm{H}_{2}{ }^{18} \mathrm{O} / \mathrm{Ar}$ and $\mathrm{CO} / \mathrm{H}_{2}{ }^{18} \mathrm{O} / \mathrm{Ar}$ (left panel) contrarily to the corresponding unlabelled gas mixtures (right panel). This behavior coincides well with the estimated isotope factor based on isolated ${ }^{16} \mathrm{O} /{ }^{18} \mathrm{O}-{ }^{1} \mathrm{H}$ harmonic oscillators. Note that isotopic dilution $([\mathrm{H}] /[\mathrm{D}]<10 \%)$ upon deuteration was would be useful to investigate hydroxyl groups dynamic since it suppresses the mechanical coupling and reduces strongly the bandwidth of $v(\mathrm{O}-\mathrm{H})$ stretching bands as previously shown in different Raman studies $[132,133]$. 

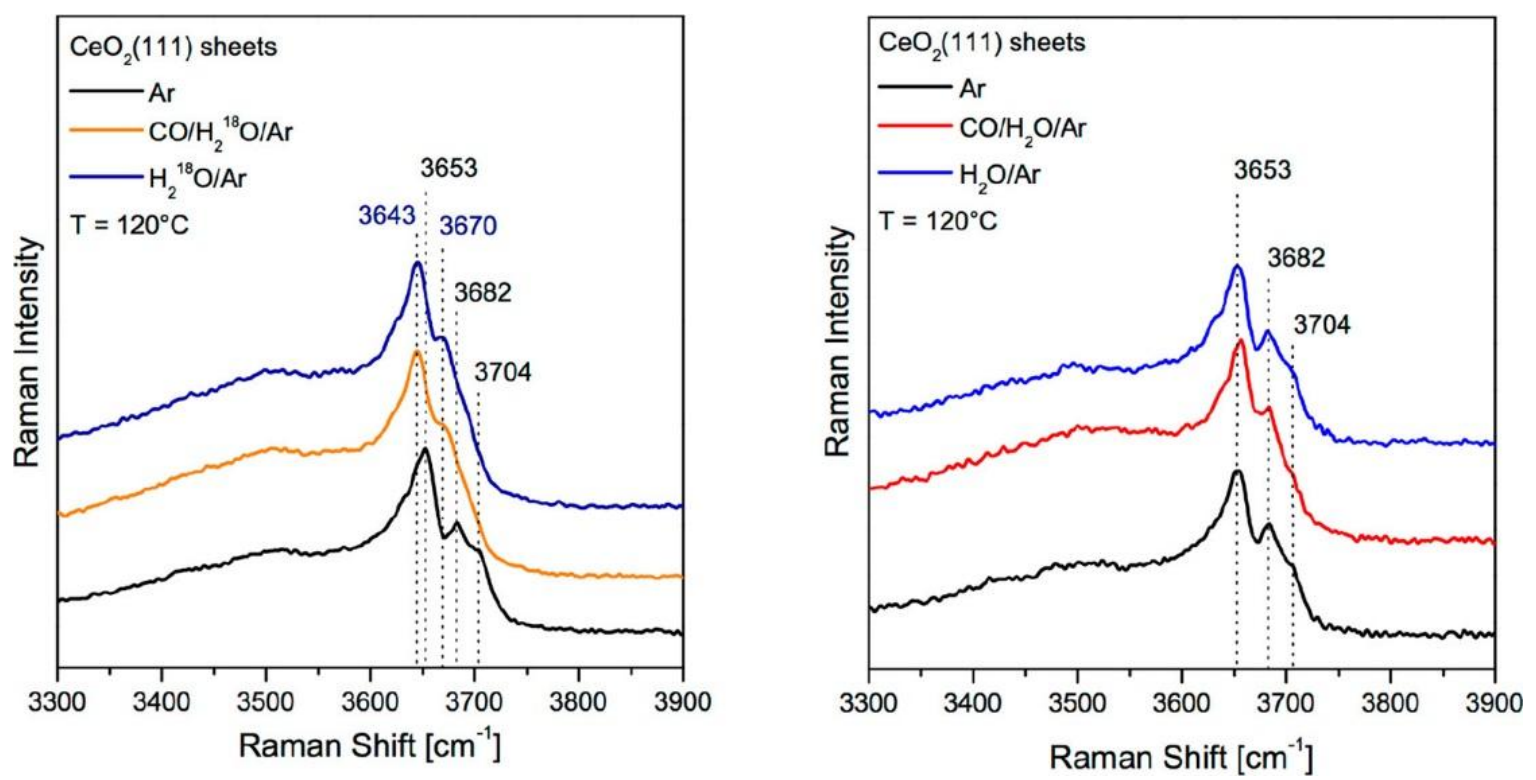

Figure 10. Raman spectra of bare $\mathrm{CeO}_{2}$ at $120{ }^{\circ} \mathrm{C}$ during exposure to WGS reaction conditions (left panel: $2 \%$ $\mathrm{CO}, 8 \% \mathrm{H}_{2}{ }^{18} \mathrm{O}$, orange; right panel: $2 \% \mathrm{CO}, 8 \% \mathrm{H}_{2}{ }^{16} \mathrm{O}$, red). For comparison, spectra in argon (black), in $8 \%$ $\mathrm{H}_{2}{ }^{18} \mathrm{O}$ (dark blue left panel), and in $8 \% \mathrm{H}_{2}{ }^{16} \mathrm{O}$ (blue right panel) are shown. Spectra are offset for clarity. Reprinted with permission from [131] Copyright 2018 American Chemical Society.

No shift of the $\mathrm{F}_{2 \mathrm{~g}}$ band was observed in bare ceria upon ${ }^{16} \mathrm{O} /{ }^{18} \mathrm{O}$ isotopic exchange indicating lattice oxygen $\left(\mathrm{O}^{2-}\right)$ was not liable to such exchange. Furthermore, as shown in Figure 11, the longitudinal and transversal stretching modes at 242 and $402 \mathrm{~cm}^{-1}$ probing the surface oxygen of the $\mathrm{CeO}_{2}$ (111) surface (see Part 2.2) disappeared in WGS reaction conditions but not under $\mathrm{H}_{2} \mathrm{O}$ /Ar flow neither $\mathrm{CO}$ oxidation reaction conditions. The different red-shifts of the $\mathrm{F}_{2 \mathrm{~g}}$ provided additional insight (see the different wavenumbers in Figure 11). In particular, it was attributed to reduction of the ceria subsurface under $\mathrm{CO} / \mathrm{H}_{2}{ }^{18} \mathrm{O} / \mathrm{Ar}$ at 120 ${ }^{\circ} \mathrm{C}$ and to large amounts of ${ }^{18} \mathrm{O}$ in the subsurface of the ceria support due to oxygen transfer from the surface to the ceria subsurface highlighting the oxygen dynamics of the ceria support. 


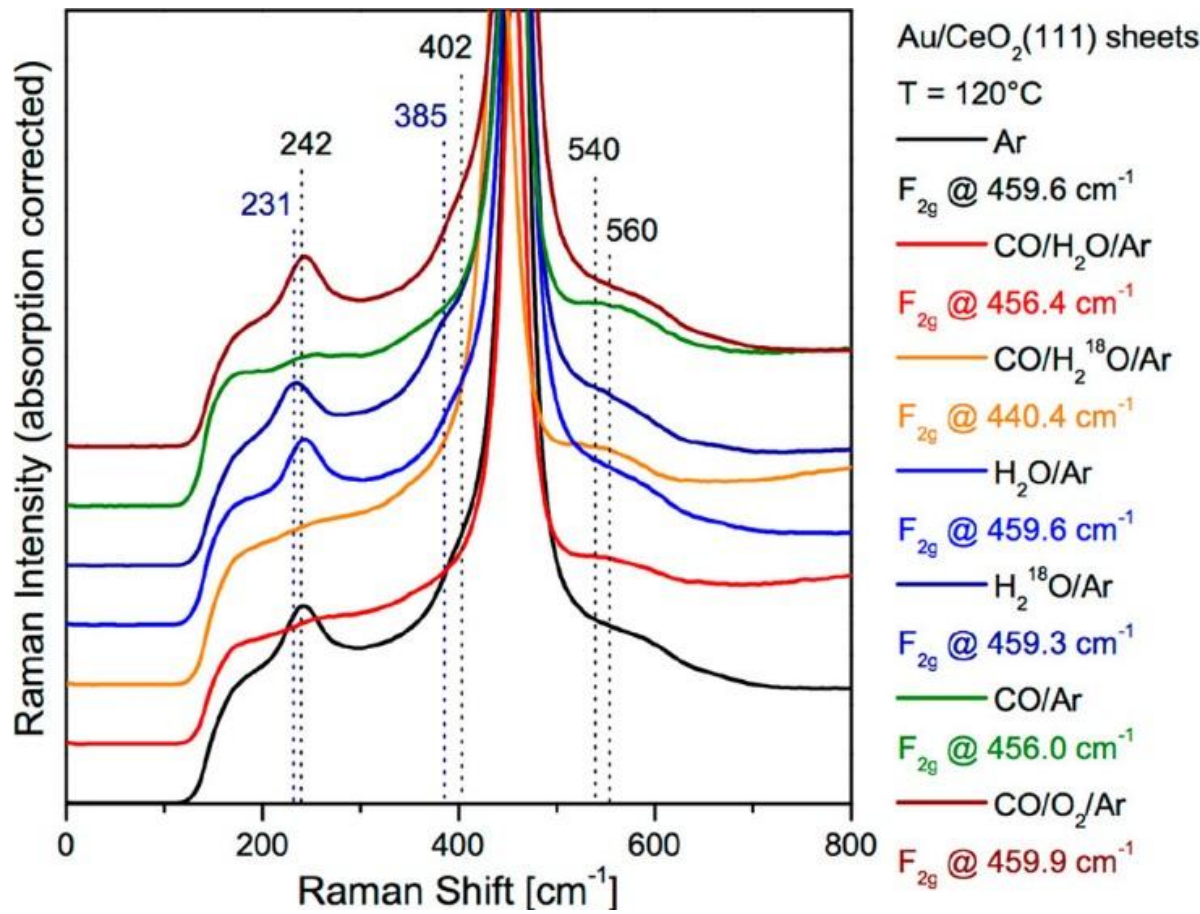

Figure 11. In situ/operando Raman spectra (phonon region) of $0.5 \mathrm{wt} \% \mathrm{Au} / \mathrm{CeO}_{2}$ at $120{ }^{\circ} \mathrm{C}$ exposed to argon (black), WGS reaction conditions $\left(2 \% \mathrm{CO}, 8 \% \mathrm{H}_{2}{ }^{16} \mathrm{O}\right.$, red), WGS reaction conditions $\left(2 \% \mathrm{CO}, 8 \% \mathrm{H}_{2}{ }^{18} \mathrm{O}\right.$, orange), $10 \% \mathrm{H}_{2}{ }^{16} \mathrm{O}$ (blue), $8 \% \mathrm{H}_{2}{ }^{18} \mathrm{O}$, (dark blue), $2 \% \mathrm{CO}$ (green), and $\mathrm{CO}$ oxidation reaction conditions (2\% $\mathrm{CO}, 10 \% \mathrm{O}_{2}$, brown). Prior to all in situ measurements, the catalyst was equilibrated in argon at $120{ }^{\circ} \mathrm{C}$. The $\mathrm{F}_{2 \mathrm{~g}}$ band is cut off, and the position of the $\mathrm{F}_{2 \mathrm{~g}}$ band is given at the right of the panel. Spectra are offset for clarity. Reprinted with permission from [131] Copyright 2018 American Chemical Society.

In situ Raman spectroscopy combined with quantitative FT-IR gas phase analysis was used to elucidate the mechanism of $\mathrm{NO}_{2}$ storage in ceria [134,135]. As shown in Figure 12c, it allowed identification of nitrites $\left(1292 \mathrm{~cm}^{-1}\right)$, free nitrates $\left(726\right.$ and $\left.1036 \mathrm{~cm}^{-1}\right)$, monodentate nitrates $\left(1248 \mathrm{~cm}^{-1}\right)$, bidentate nitrates $\left(1556-1605 \mathrm{~cm}^{-1}\right)$ and bridging nitrates $\left(1622 \mathrm{~cm}^{-1}\right)$. Furthermore, a $\mathrm{F}_{2 \mathrm{~g}}$ red shift of $1.5 \mathrm{~cm}^{-1}$ and an intensity loss (Figure 12a) were observed over the whole $60 \mathrm{~min}$ of $\mathrm{NO}_{2}$ storage which is caused by formation of oxygen vacancies in the lattice. A similar temporal behavior was evidenced for the surface modes (bands at 250 and $407 \mathrm{~cm}^{-1}$ ) describing a dependence of bulk defects on surface oxygen consumption. It was further concluded that the Ce-O surface sites play a key role for NOx storage, as their amount strongly influences the NOx storage capacity. Note that the $v(\mathrm{OH})$ band also decreased upon $\mathrm{NO}_{2}$ exposure but faster: after 35 min no more hydroxides could be detected (see Fig. 12d), while surface oxygen was still observable (see Fig. 12b). 

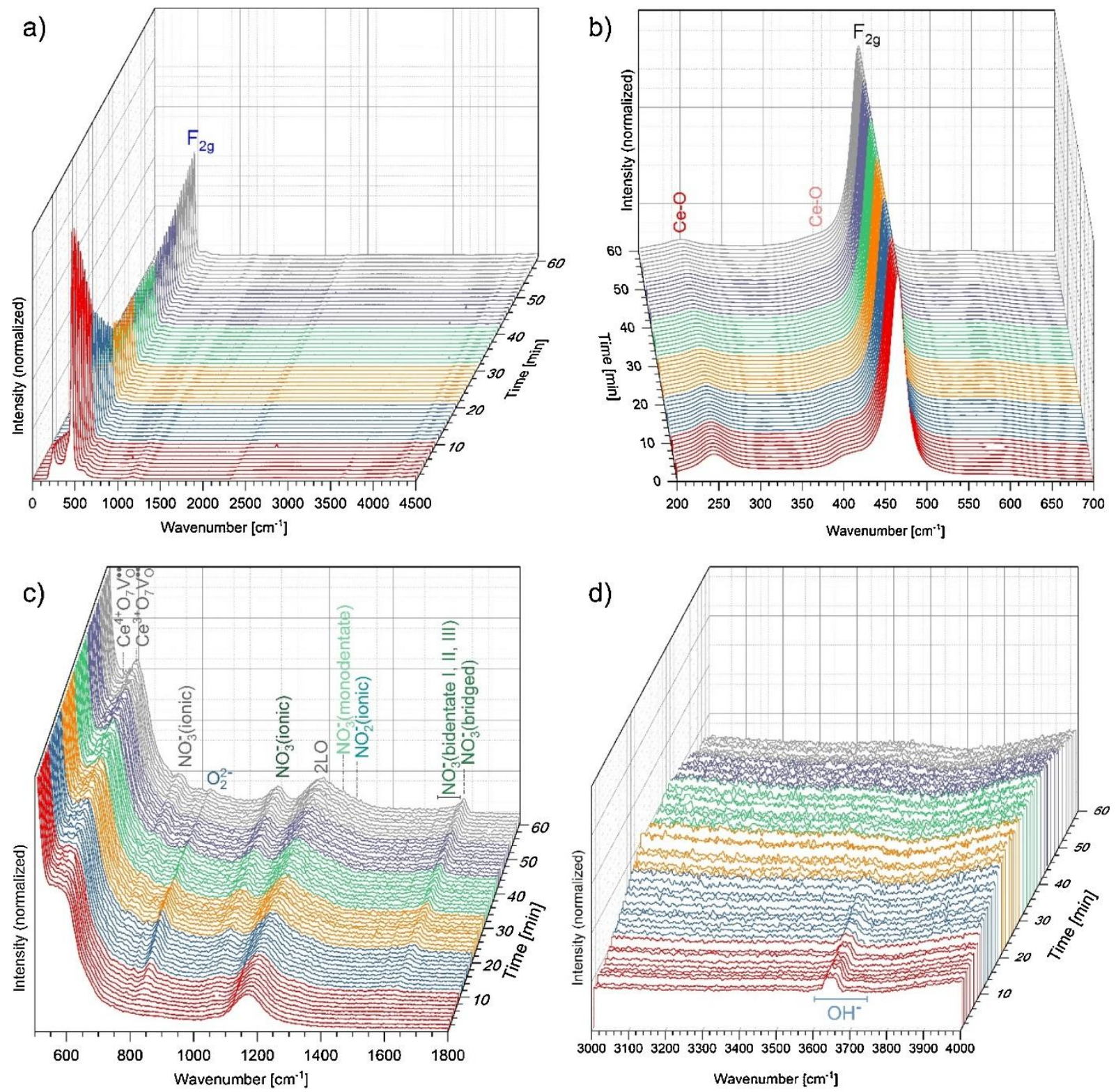

Figure 12. (a) In situ Raman spectra of oxidatively treated ceria showing the temporal evolution upon exposure to $500 \mathrm{ppm} \mathrm{NO} / 20 \% \mathrm{O}_{2} / \mathrm{N}_{2}$ at $30{ }^{\circ} \mathrm{C}$. An enlarged view of the Raman spectra is shown for the regions (b) 200 $700 \mathrm{~cm}^{-1}$, (c) $500-1800 \mathrm{~cm}^{-1}$, and (d) $3000-4000 \mathrm{~cm}^{-1}$ after normalization by the $\mathrm{F}_{2 \mathrm{~g}}$ intensity to correct absorption effects. Reprinted with permission from [135] Copyright 2018 Elsevier B.V. All rights reserved.

\section{Conclusions and perspectives}

Considering the cubic fluorite structure of ceria, interpretation of its Raman spectra could be limited to the wavenumber, width and intensity of the $F_{2 g}$ band. However, more detailed structural properties can be obtained from small bands such as surface modes around 250 and $405 \mathrm{~cm}^{-1}$, defect modes between 550 and $600 \mathrm{~cm}^{-1}$, stretching vibrations of peroxo, superoxo and $\mathrm{OH}$ groups at $800-900,1100-1200 \mathrm{~cm}^{-1}$ and $3600-3700 \mathrm{~cm}^{-1}$, respectively as well as electronic Raman scattering of $\mathrm{Ce}^{3+}$ cations at $2130 \mathrm{~cm}^{-1}$. In the case of catalysts supported over $\mathrm{CeO}_{2}$, additional bands due to supported molecular species and crystalline phases can be 
observed. Therefore, Raman spectroscopy is very powerful to investigate structural properties of ceria-based catalysts and has been widely used for ex situ, in situ and operando experiments which were reviewed in this paper. In the future, new field of investigation such as in situ Raman images to investigate structural evolutions [110,136-140], in situ Tip Enhanced Raman Spectroscopy (TERS) to reach high spatial resolution [141-144] and chemometric tools to extract subtle data [145-148] should be applied widening the field of Raman applications to ceria-based catalysts. 


\section{References}

[1] P. Li, X. Chen, Y. Li, J.W. Schwank, A review on oxygen storage capacity of $\mathrm{CeO}_{2}$-based materials: Influence factors, measurement techniques, and applications in reactions related to catalytic automotive emissions control, Catal. Today 327 (2019) 90-115.

[2] D. Devaiah, L.H. Reddy, S.-E. Park, B.M. Reddy, Ceria-zirconia mixed oxides: Synthetic methods and applications, Catal. Rev.: Sci. Eng. 60 (2018) 177-277.

[3] T. Montini, M. Melchionna, M. Monai, P. Fornasiero, Fundamentals and Catalytic Applications of $\mathrm{CeO}_{2}$-Based Materials, Chem. Rev. 116 (2016) 5987-6041.

[4] D. Mukherjee, B.M. Reddy, Noble metal-free $\mathrm{CeO}_{2}$-based mixed oxides for $\mathrm{CO}$ and soot oxidation, Catalysis Today 309 (2018), 309, 227-235.

[5] S. Liu, X. Wu, D. Weng, R. Ran, Ceria-based catalysts for soot oxidation: a review, J. Rare Earths 33 (2015) 567-590.

[6] J. Xu, H. Yu, C. Zhang, F. Guo, J. Xie, Development of cerium-based catalysts for selective catalytic reduction of nitrogen oxides: a review, New J. Chem. 43 (2019) 3996-4007. [7] C. Tang, H. Zhang, L. Dong, Ceria-based catalysts for low-temperature selective catalytic reduction of NO with NH3, Catal. Sci. Tech. 6 (2016) 1248-1264.

[8] Q. Wang, K. L. Yeung, M. A. Banares, Ceria and its related materials for VOC catalytic combustion: A review, Catalysis Today (2019), Ahead of Print.

[9] U. Tumuluri, G. Rother, Z. Wu, Zili, Fundamental Understanding of the Interaction of Acid Gases with $\mathrm{CeO}_{2}$ : Surface Science to Practical Catalysis, Industrial \& Engineering Chemistry Research 55 (2016) 3909-3919.

[10] A. Kubacka, A. Martinez-Arias, M. Fernandez-Garcia, Role of the Interface in BaseMetal Ceria-Based Catalysts for Hydrogen Purification and Production Processes, ChemCatChem 7 (2015) 3614-3624.

[11] F. Wang, M. Wei, D.G. Evans, X. Duan, $\mathrm{CeO}_{2}$-based heterogeneous catalysts toward catalytic conversion of $\mathrm{CO}_{2}$, J. Mater. Chem. A 4 (2016) 5773-5783.

[12] G. Lafaye, J. Barbier, D. Duprez, Impact of cerium-based support oxides in catalytic wet air oxidation: Conflicting role of redox and acid-base properties, Catal. Today 253 (2015) 8998.

[13] A. Trovarelli, J. Llorca, Ceria Catalysts at Nanoscale: How Do Crystal Shapes Shape Catalysis? ACS Catal. 7 (2017) 4716-4735.

[14] M. Nolan, Surface effects in the reactivity of ceria: a first principles perspective, in: Z. Wu, S.H. Overbury (Eds), Catalysis by Materials with Well-Defined Structures, Elsevier, 2015, Chapter 6, pp159-192. 
[15] A.K.P. Mann, Z. Wu, S.H. Overbury, The characterization and structure-dependent catalysis of ceria with well-defined facets, in: Z. Wu, S.H. Overbury (Eds), Catalysis by Materials with Well-Defined Structures, Elsevier, 2015, Chapter 3, pp71-97.

[16] S. Agarwal, B.L. Mojet, L. Lefferts, A.K. Datye, Ceria nanoshapes-structural and catalytic properties, in : Z. Wu, S.H. Overbury (Eds), Catalysis by Materials with WellDefined Structures, Elsevier, 2015, Chapter 2, pp, 31-70.

[17] R.W. McCabe, A. Trovarelli, Forty years of catalysis by ceria: A success story, Applied Catalysis, B: Environmental 197 (2016) 1.

[18] M.V. Ganduglia-Pirovano, The non-innocent role of cerium oxide in heterogeneous catalysis: A theoretical perspective, Catal. Today 253 (2015) 20-32.

[19] M.S. Hegde, P. Bera, Noble metal ion substituted $\mathrm{CeO}_{2}$ catalysts: Electronic interaction between noble metal ions and $\mathrm{CeO}_{2}$ lattice, Catal. Today 253 (2015 40-50.

[20] S. Loridant, Raman Spectroscopy of Nanomaterials: Applications to Heterogeneous Catalysis, in O. S. Oluwafemi, S. Thomas, N. Kalarikkal, S. Mohan (Eds), Characterization of Nanomaterials: Advances and Key Technologies-Volume II, Elsevier, 2018, Chapter 2, pp3759.

[21] G. Gouadec, P. Colomban, Raman Spectroscopy of nanomaterials: How spectra relate to disorder, particle size and mechanical properties, Progr. Cryst. Growth Charact. Mater. 53 (2007) 1-56.

[22] S. Mochizuki, infrared Optical Properties of Cerium Dioxide, Phys. Stat. Sol. 114 (1982) 189-199.

[23] T. Shimanouchi, M. Tsuboi, T.Miyazawa, Optically Active Lattice Vibrations as Treated by the GF-Matrix Method, J. Chem. Phys. 35 (1961) 1597-1612.

[24] W. Weber, K. Hass, J. McBride, Raman Study of $\mathrm{CeO}_{2}$ : Second-Order Scattering, Lattice Dynamics, and Particle-Size Effects, Phys. Rev. B: Condens. Matter Mater. Phys. 48 (1993) $178-185$.

[25] J. Buckeridge, D.O. Scanlon, A. Walsh, C.R.A. Catlow, A.A. Sokol, Dynamical Response and Instability in Ceria under Lattice Expansion, Phys. Rev. B: Condens. Matter Mater. Phys. 87 (2013) 214304.

[26] C. Schilling, A. Hofmann, C. Hess, M.V. Ganduglia-Pirovano, Raman Spectra of Polycrystalline $\mathrm{CeO}_{2}$ : A Density Functional Theory Study, J. Phys. Chem. C 2017, 121, 20834-20849.

[27] J.E. Spanier, R.D. Robinson, F. Zhang, S.-W. Chan, I.P. Herman, Size-Dependent Properties of $\mathrm{CeO}_{2-\mathrm{y}}$ Nanoparticles as Studied by Raman Scattering. Phys. Rev. B: Condens. 
Matter Mater. Phys. 64 (2001) 245407.

[28] I. Kosacki, T. Suzuki, V Petrovsky, H. U. Anderson, P. Colomban, Lattice defects in nanocrystalline $\mathrm{CeO}_{2}$ thin films, Radiation Effects \& Defects in Solids 156 (2001) 109-115.

[29] I. Kosacki, T. Suzuki, H.U. Anderson, P. Colomban, Raman scattering and lattice defects in nanocrystalline $\mathrm{CeO}_{2}$ thin films, Solid State Ionics 149 (2002) 99-105.

[30] H. Richter, Z.P. Wang, L. Ley, The one phonon spectrum in microcrystalline silicon, Solid State Commun. 39 (1981) 625-629.

[31] Z.V. Popovic, Z. Dohcevic-Mitrovic, M.J. Konstantinovic, M. Scepanovic, Raman scattering characterization of nanopowders and nanowires (rods), J. Raman Spectrosc. 38 (2007) 750-755.

[32] M. Grujic-Brojcin, M.J. Scepanovic, Z.D. Dohcevic-Mitrovic, Z.V. Popovic, Use of phonon confinement model in simulation of Raman spectra of nanostructured materials, Acta Phys. Pol. A 116 (2009), 51-54.

[33] A. Filtschew, K. Hofmann, C. Hess, Ceria and Its Defect Structure: New Insights from a Combined Spectroscopic Approach, J. Phys. Chem. C 120 (2016) 6694-6703.

[34] C.C. Yang, S. Li, Size-Dependent Raman Red Shifts of Semiconductor Nanocrystals, J. Phys. Chem. B 112 (2008) 14193-14197.

[35] Z.V. Popovic, Z. Dohcevic-Mitrovic, A. Cros, A. Cantarero, Raman scattering study of the anharmonic effects in $\mathrm{CeO}_{2-y}$ nanocrystals, J. Phys.: Condens. Matter 19 (2007) 496209/1$496209 / 9$.

[36] A.C. Oliveira, A.N. da Silva, J.A.L. Junior, P.T.C. Freire, A.C. Oliveira, J.M. Filho, Structural changes in nanostructured catalytic oxides monitored by Raman spectroscopy: Effect of the laser heating, J. Phys. Chem. Solids 102 (2017) 90-98.

[37] H. Zhu, C. Yang, Q. Li, Y. Ren, J.C. Neuefeind, L. Gu, H. Liu, L. Fan, J. Chen, J. Deng, N. Wang, J. Hong, X. Xing, Charge transfer drives anomalous phase transition in ceria, Nat. Commun. 9 (2018) 1-8.

[38] B.M. Reddy, P. Lakshmanan, A. Khan, S. Loridant, C. Lopez-Cartes, T.C. Rojas, A. Fernandez, Surface Stabilized Nanosized $\mathrm{Ce}_{\mathrm{x}} \mathrm{Zr}_{1-\mathrm{x}} \mathrm{O}_{2}$ Solid Solutions over $\mathrm{SiO}_{2}$ : Characterization by XRD, Raman, and HREM Techniques, J. Phys. Chem. B 109 (2005) 13545-13552.

[39] Z. Wu, M. Li, J. Howe, H.M. Meyer III, S.H. Overbury, Probing Defect Sites on $\mathrm{CeO}_{2}$ Nanocrystals with Well-Defined Surface Planes by Raman Spectroscopy and $\mathrm{O}_{2}$ Adsorption, Langmuir 26 (2010) 16595-16606.

[40] S. Agarwal, X. Zhu, E. J. M. Hensen, B. L. Mojet and L. Lefferts, Surface-Dependence 
of Defect Chemistry of Nanostructured Ceria, J. Phys. Chem. C 119 (2015) 12423-12433.

[41] C. Paun, O.V. Safonova, J. Szlachetko, P.M. Abdala, M. Nachtegaal, J. Sa, E. Kleymenov, A. Cervellino, F. Krumeich, J.A. van Bokhoven, Polyhedral $\mathrm{CeO}_{2}$ Nanoparticles: Size-Dependent Geometrical and Electronic Structure, J. Phys. Chem. C 2012, $116,7312-7317$.

[42] T. Taniguchi, T. Watanabe, N. Sugiyama, A.K. Subramani, H. Wagata, N. Matsushita, M. Yoshimura, Identifying Defects in Ceria-Based Nanocrystals by UV Resonance Raman Spectroscopy. J. Phys. Chem. C 113 (2009) 19789-19793.

[43] P.C. Stair, The Application of UV Raman Spectroscopy for the Characterization of Catalysts and Catalytic Reactions, Adv. Catal. 51 (2007) 75-98.

[44] M. Daniel, S. Loridant, Probing reoxidation sites by in situ Raman spectroscopy: differences between reduced $\mathrm{CeO}_{2}$ and $\mathrm{Pt} / \mathrm{CeO}_{2}$, J. Raman Spectrosc. 43 (2012) 1312-1319.

[45] V.V. Pushkarev, V.I. Kovalchuk, J.L. d'Itri, Probing Defect Sites on the $\mathrm{CeO}_{2}$ Surface with Dioxygen. J. Phys. Chem. B 108 (2004) 5341-5348.

[46] G. Ferré, L. Burel, M. Aouine, F. Bosselet, S. Ntais, T. Epicier, F.J. Cadete Santos Aires, C. Geantet, A. Gaenzler, F. Maurer, M. Casapu, J.-D. Grunwaldt, S. Loridant, P. Vernoux, Exploiting the dynamic properties of Pt on ceria for low temperature CO oxidation, Appl. Catal. B, submitted.

[47] S. Wang, W. Wang, J. Zuo, Y. Qian, Study of the Raman spectrum of $\mathrm{CeO}_{2}$ nanometer thin films, Mater. Chem. Phys. 68 (2001) 246-248.

[48] S. Agarwal, L. Lefferts, B.L. Mojet, Ceria Nanocatalysts: Shape Dependent Reactivity and Formation of OH, ChemCatChem 5 (2013) 479-489.

[49] I. Trenque, G.C. Magnano, M.A. Bolzinger, L. Roiban, F. Chaput, I. Pitault, S. Briançon, T. Deverse, K. Masenelli-Varlot, M. Bugnet D. Amans, Shape-selective synthesis of nanoceria for degradation of paraoxon as chemical warfare simulant, Phys. Chem. Chem. Phys. 21( 2019) 5455-5465.

[50] Q. Dai, H. Huang, Y. Zhu, W. Deng, S. Bai, X. Wang, G. Lu, Catalysis oxidation of 1,2dichloroethane and ethyl acetate over ceria nanocrystals with well-defined crystal planes, Appl. Catal.B: Environmental 117-118 (2012) 360-368.

[51] F. Vindigni, M. Floriana, D. Maela, T. Alessandro, T. Tabakova, A. Zecchina, Surface and Inner Defects in $\mathrm{Au} / \mathrm{CeO}_{2}$ WGS Catalysts: Relation between Raman Properties, Reactivity and Morphology, Chem. Eur. J. 17 (2011) 4356-4361.

[52] D. Avisar, T. Livneh, The Raman-Scattering of A-Type $\mathrm{Ce}_{2} \mathrm{O}_{3}$, Vib. Spectrosc. 86 (2016) $14-16$. 
[53] V.M. Orera, R.I. Merino and F. Pena, $\mathrm{Ce}^{3+} \leftrightarrow \mathrm{Ce}^{4+}$ conversion in ceria-doped zirconia single crystals induced by oxido-reduction treatments, Solid State Ion. 72 (1994) 224-231.

[54] S. Urban, I. Djerdj, P. Dolcet, L. Chen, M. Möller, O. Khalid, H. Camuka, R. Ellinghaus, C. Li, S. Gross, P.J. Klar, B. Smarsly, H. Over, In Situ Study of the Oxygen-Induced Transformation of Pyrochlore $\mathrm{Ce}_{2} \mathrm{Zr}_{2} \mathrm{O}_{7+\mathrm{x}}$ to the $\kappa^{-} \mathrm{Ce}_{2} \mathrm{Zr}_{2} \mathrm{O}_{8}$ Phase, Chem. Mater. 29 (2017) 9218-9226.

[55] T. Otake, H. Yugami, H. Naito, K. Kawamura, T. Kawada, J. Mizusaki, Ce ${ }^{3+}$ concentration in $\mathrm{ZrO}_{2}-\mathrm{CeO}_{2}-\mathrm{Y}_{2} \mathrm{O}_{3}$ system studied by electronic Raman scattering, Solid State Ion. 135 (2000) 663-667.

[56] P.B. Oliete, A. Orera, M. L. Sanjuán, Spectroscopic insight into the interplay between structural disorder and oxidation degree in melt- grown $\mathrm{Ce}_{0.5} \mathrm{Zr}_{0.5} \mathrm{O}_{2-\text { y }}$ compounds, J. Raman Spectrosc. (2020) 1-14.

[57] C. Binet, A. Badri, J.-C. Lavalley, A Spectroscopic Characterization of the Reduction of Ceria from Electronic Transitions of Intrinsic Point Defects, J. Phys. Chem. 98 (1994) 63926398.

[58] A. Badri, C. Binet, J.-C. Lavalley, An FTIR study of surface ceria hydroxy groups during a redox process with $\mathrm{H}_{2}$, J. Chem. Soc., Faraday Trans. 92 (1996) 4669-4673.

[59] C.T. Nottbohm, C. Hess, Investigation of ceria by combined Raman, UV-vis and X-ray photoelectron spectroscopy, Catal. Commun. 22 (2012) 39-42.

[60] Z. Wu, Y. Cheng, F. Tao, L. Daemen, G.S. Foo, L. Nguyen, X. Zhang, A. Beste, A.J. Ramirez-Cuesta, Direct Neutron Spectroscopy Observation of Cerium Hydride Species on a Cerium Oxide Catalyst, J. Am. Chem. Soc. 139 (2017) 9721-9727.

[61] J.R. McBride, K.C. Hass, B.D. Poindexter, W.H. Weber, Raman and X-ray studies of $\mathrm{Ce}_{1-\mathrm{x}} \mathrm{RE}_{\mathrm{x}} \mathrm{O}_{2-\mathrm{y}}$, where RE=La, Pr, Nd, Eu, Gd, and Tb, J. Appl. Phys. 76 (1994) 2435-2441.

[62] A. Mineshige, T. Taji, Y. Muroi, M. Kobune, S. Fujii, N. Nishi, M. Inaba, Z. Ogumi, Oxygen chemical potential variation in ceria-based solid oxide fuel cells determined by Raman spectroscopy, Solid State Ion. 135 (2000) 481-485.

[63] Z.D. Dohcevic-Mitrovic, M. Grujic-Brojcin, M. Scepanovic, Z.V. Popovic, S. Boskovic, B. Matovic, M. Zinkevich, F. Aldinger, $\mathrm{Ce}_{1-\mathrm{x}} \mathrm{Y}(\mathrm{Nd})_{\mathrm{x}} \mathrm{O}_{2-\delta}$ nanopowders: potential materials for intermediate temperature solid oxide fuel cells, J. Phys.: Condens. Matter 18 (2006) S2061-S2068.

[64] M. Guo, J. Lu, Y. Wu, Y. Wang, M. Luo, UV and Visible Raman Studies of Oxygen Vacancies in Rare-Earth-Doped Ceria, Langmuir 27 (2011) 3872-3877.

[65] N. Paunovic, Z. Dohcevic-Mitrovic, R. Scurtu, S. Askrabic, M. Prekajski, B. Matovic, 
Z.V. Popovic, Suppression of inherent ferromagnetism in Pr-doped $\mathrm{CeO}_{2}$ nanocrystals, Nanoscale 4 (2012) 5469-5476.

[66] W. Lee, S.-Y. Chen, Y.-S. Chen, C.-L. Dong, H.-J. Lin, C.-T. Chen, A. Gloter, Defect Structure Guided Room Temperature Ferromagnetism of $\mathrm{Y}$-Doped $\mathrm{CeO}_{2}$ Nanoparticles, J. Phys. Chem. C 118 (2014) 26359-26367.

[67] W. Lee, S.-Y. Chen, E. Tseng, A. Gloter, C.-L. Chen, Study of Defect Structure in Ferromagnetic Nanocrystalline $\mathrm{CeO}_{2}$ : Effect of Ionic Radius, J. Phys. Chem. C 120 (2016) 14874-14882.

[68] A. Nakajima, A. Yoshihara, M. Ishigame, Defect-induced Raman spectra in doped $\mathrm{CeO}_{2}$, Phys. Rev. B: Condens. Matter Mater. Phys. 50 (1994) 13297-13307.

[69] L. Li, F. Chen, J.-Q Lu, M.-F. Luo, Study of Defect Sites in $\mathrm{Ce}_{1-\mathrm{x}} \mathrm{MO}_{2-\delta}(\mathrm{x}=0.2)$ Solid Solutions Using Raman Spectroscopy, J. Phys. Chem. A 115 (2011) 7972-7977.

[70] D. Avram, M. Sanchez-Dominguez, B. Cojocaru, M. Florea, V. Parvulescu, C. Tiseanu, Toward a Unified Description of Luminescence-Local Structure Correlation in Ln Doped $\mathrm{CeO}_{2}$ Nanoparticles: Roles of Ln Ionic Radius, Ln Concentration, and Oxygen Vacancies, J. Phys. Chem. C 119 (2015) 16303-16313.

[71] Y. Xu, F. Wang, X. Liu, Y. Liu, M. Luo, B. Teng, M. Fan, X. Liu, Resolving a DecadeLong Question of Oxygen Defects in Raman Spectra of Ceria-Based Catalysts at Atomic Level, J. Phys. Chem. C, doi.org/10.1021/acs.jpcc.9b00633.

[72] A. Westermann, C. Geantet, P. Vernoux, S. Loridant, Defects band enhanced by resonance Raman effect in praseodymium doped $\mathrm{CeO}_{2}$, J. Raman Spectrosc. 47 (2016) 12761279.

[73] P. Fornasiero, A. Speghini, R. Di Monte, M. Bettinelli, J. Kaspar, A. Bigotto, V. Sergo, M. Graziani, Laser-Excited Luminescence of Trivalent Lanthanide Impurities and Local Structure in $\mathrm{CeO}_{2}-\mathrm{ZrO}_{2}$ Mixed Oxides, Chem. Mater. 16 (2004) 1938-1944.

[74] J. Twu, C.J. Chuang, K.I. Chang, C.H. Yang, K.H. Chen, Raman spectroscopic studies on the sulfation of cerium oxide, Appl. Catal. B: Environmental 12 (1997) 309-324.

[75] R. Flouty, E. Abi-Aad, S. Siffert, A. Aboukais, Formation of cereous sulphate phase upon interaction of $\mathrm{SO}_{2}$ with ceria at room temperature, J. Therm. Anal. Calorim. 73 (2003) 727-734.

[76] D. Uy, A.E. O'Neill, L. Xu, W.H. Weber, R.W. McCabe, Observation of cerium phosphate in aged automotive catalysts using Raman spectroscopy, Appl. Catal. B: Environmental 41 (2003) 269-278.

[77] B.M. Reddy, A. Khan, P. Lakshmanan, M. Aouine, S. Loridant, J.-C. Volta, Structural 
Characterization of Nanosized $\mathrm{CeO}_{2}-\mathrm{SiO}_{2}, \mathrm{CeO}_{2}-\mathrm{TiO}_{2}$, and $\mathrm{CeO}_{2}-\mathrm{ZrO}_{2}$ Catalysts by XRD, Raman, and HREM Techniques, J. Phys. Chem. B 109 (2005) 3355-3363.

[78] B.M. Reddy, A. Khan, Y. Yamada, T. Kobayashi, S. Loridant, J.-C. Volta, Structural Characterization of $\mathrm{CeO}_{2}-\mathrm{MO}_{2}\left(\mathrm{M}=\mathrm{Si}^{4+}, \mathrm{Ti}^{4+}\right.$, and $\left.\mathrm{Zr}^{4+}\right)$ Mixed Oxides by Raman Spectroscopy, X-ray Photoelectron Spectroscopy, and Other Techniques, J. Phys. Chem. B 107 (2003) 11475-11484.

[79] R. Di Monte, J. Kaspar, Nanostructured $\mathrm{CeO}_{2}-\mathrm{ZrO}_{2}$ mixed oxides, J. Mater. Chem. 15 (2005) 633-648.

[80] F. Zhang, C.-H. Chen, J.C. Hanson, R.D. Robinson, I.P. Herman, S.-W. Chan, Phases in ceria-zirconia binary oxide (1-x) $\mathrm{CeO}_{2}-\mathrm{xZrO}_{2}$ nanoparticles: the effect of particle size, J. Am. Ceram. Soc. 89 (2006) 1028-1036.

[81] I. Fabregas, R.O. Fuentes, D.G. Lamas, M.E. Fernandez de Rapp, N.E. Walsoe de Reca, M.C.A Fantini, A.F. Craievich, R.J. Prado, R.P. Millen, M.L.A. Temperini, Local structure of the metal-oxygen bond in compositionally homogeneous, nanocrystalline zirconia-ceria solid solutions synthesized by a gel-combustion process, J. Phys. Condens. Matter 18 (2006) 7863 7881.

[82] M. Yashima, H. Arashi, M. Kakihana, M. Yoshimura, Raman Scattering Study of CubicTetragonal Phase Transition in $\mathrm{Zr}_{1-\mathrm{x}} \mathrm{Ce}_{\mathrm{x}} \mathrm{O}_{2}$ Solid Solution, J. Am Ceram. Soc. 77 (1994) $1067-$ 1071.

[83] M.L. Sanjuán, P.B. Oliete, A. Várez, J. Sanz, The role of Ce reduction in the segregation of metastable phases in the $\mathrm{ZrO}_{2}-\mathrm{CeO}_{2}$ system, J. Eur. Ceram. Soc. 32 (2012) 689-696.

[84] R. Si, Y.-W. Zhang, S.-J. Li, B.-X. Lin, C.-H. Yan, Urea-Based Hydrothermally Derived Homogeneous Nanostructured $\mathrm{Ce}_{1-\mathrm{x}} \mathrm{Zr}_{\mathrm{x}} \mathrm{O}_{2}(\mathrm{x}=0-0.8)$ Solid Solutions: A Strong Correlation between Oxygen Storage Capacity and Lattice Strain, J. Phys. Chem. B 108 (2004) 1248112488.

[85] B.M. Reddy, A. Khan, Y. Yamada, T. Kobayashi, S. Loridant, J.-C. Volta, Raman and X-ray Photoelectron Spectroscopy Study of $\mathrm{CeO}_{2}-\mathrm{ZrO}_{2}$ and $\mathrm{V}_{2} \mathrm{O}_{5} / \mathrm{CeO}_{2}-\mathrm{ZrO}_{2}$ Catalysts, Langmuir 19 (2003) 3025-3030.

[86] R.D. Shannon, Revised effective ionic radii and systematic studies of interatomic distances in halides and chalcogenides, Acta Crystallogr. Sect. A: Cryst. Phys. Diffr. Theor. Gen. Crystallogr. 32 (1976) 751-767.

[87] T. Taniguchi, T. Watanebe, S. Ichinohe, M. Yoshimura, K.-I. Katsumata, K. Okada, N. Matsushita, Nanoscale heterogeneities in $\mathrm{CeO}_{2}-\mathrm{ZrO}_{2}$ nanocrystals highlighted by UVresonant Raman spectroscopy, Nanoscale 2 (2010) 1426-1428. 
[88] F. Zhang, C. H. Chen, J. M. Raitano, J. C. Hanson, W. A. Caliebe, S. Khalid, S. W. Chan, Phase stability in ceria-zirconia binary oxide nanoparticles: The effect of the $\mathrm{Ce}^{3+}$ concentration and the redox environment, J. Appl. Phys. 99 (2006) 084313.

[89] C. Andriopoulou, A. Trimpalis, K.C. Petallidou, A. Sgoura, A.M. Efstathiou, S. Boghosian, Structural and Redox Properties of $\mathrm{Ce}_{1-\mathrm{x}} \mathrm{Zr}_{\mathrm{x}} \mathrm{O}_{2-\delta}$ and $\mathrm{Ce}_{0.8} \mathrm{Zr}_{0.15} \mathrm{RE}_{0.05} \mathrm{O}_{2-\delta}$ (RE: La, Nd, Pr, Y) Solids Studied by High Temperature in Situ Raman Spectroscopy, J. Phys. Chem. C121 (2017) 7931-7943.

[90] S. Otsuka-Yao-Matsuo, T. Omata, N. Izu, H. Kishimoto, Oxygen Release Behavior of $\mathrm{CeZrO}_{4}$ Powders and Appearance of New Compounds $\kappa$ and $t^{*}$, J. Solid State Chem. 138 (1998) 47-54.

[91] W.H. Weber, Raman applications in catalysts for exhaust-gas treatment, in: W.H. Weber, R. Merlin (Eds.), Springer Series in Materials Science, vol.42 (Raman Scattering in Materials Science), Springer-Verlag, 2000, pp. 233-270.

[92] J.R. McBride, G.W. Graham, C.R. Peters, W.H. Weber, Growth and Characterization of reactively sputtered thin-film platinum oxides, J. Appl. Phys. 69 (1991) 1596-1604.

[93] G.W. Graham, A.E. O'Neill, D. Uy, W.H. Weber, H. Sun, X.Q. Pan, Observation of strained PdO in an aged Pd/ceria-zirconia catalyst, Catal. Lett. 79 (2002) 99-105.

[94] R.V.Gulyaev, T.Y Kardash, S.E. Malykhin, O.A. Stonkus, A.S. Ivanova, A.I. Boronin, The local structure of $\mathrm{Pd}_{\mathrm{x}} \mathrm{Ce}_{1-\mathrm{x}} \mathrm{O}_{2-\mathrm{x}-\delta}$ solid solutions, Phys. Chem. Chem. Phys. 16 (2014) 13523-13539.

[95] L.S. Kibis, T.Y. Kardash, E.A. Derevyannikova, O.A. Stonkus, E.M. Slavinskaya, V.A. Svetlichnyi, A.I. Boronin, Redox and Catalytic Properties of $\mathrm{Rh}_{\mathrm{x}} \mathrm{Ce}_{1-\mathrm{x}} \mathrm{O}_{2-\delta}$ Solid Solution, J. Phys. Chem. C 121 (2017) 26925-26938.

[96] L.L. Murrell, S.J. Tauster, D.R. Anderson, Laser Raman Characterization of Surface Phase Precious Metal Oxides Formed on $\mathrm{CeO}_{2}$, Stud. Surf. Sci. Catal. 71 (1991) 275-89.

[97] M.S. Brogan, T.J. Dines, J.A. Cairns, Raman spectroscopic study of the Pt-CeO interaction in the $\mathrm{Pt} / \mathrm{Al}_{2} \mathrm{O}_{3}-\mathrm{CeO}_{2}$ catalyst, J. Chem. Soc. Faraday Trans. 90 (1994) 1461-1466. [98] W. Lin, A.A. Herzing, C.J. Kiely, I.E. Wachs, Probing Metal-Support Interactions under Oxidizing and Reducing Conditions: In Situ Raman and Infrared Spectroscopic and Scanning Transmission Electron Microscopic-X-ray Energy-Dispersive Spectroscopic Investigation of Supported Platinum Catalysts, J. Phys. Chem. C 112 (2008) 5942-5951.

[99] J. Lee, Y.S. Ryou, X. Chan, T.J. Kim, D.H. Kim, How Pt Interacts with $\mathrm{CeO}_{2}$ under the Reducing and Oxidizing Environments at Elevated Temperature: The Origin of Improved Thermal Stability of Pt/CeO ${ }_{2}$ Compared to $\mathrm{CeO}_{2}$, J. Phys. Chem. C 120 (2016) 25870-25879. 
[100] Q. Wu, J. Ba, X. Yan, J. Bao, Z. Huang, S. Dou, D. Dai, T. Tang, W. Luo, D. Meng, Insight of Pt-support interaction in $\mathrm{S}-\mathrm{Pt} / \mathrm{Ce}_{0.7} \mathrm{Zr}_{0.3} \mathrm{O}_{2}$ by in situ Raman spectroscopy, Catal. Commun. 98 (2017) 34-37.

[101] T.-S. Nguyen, G. Postole, S. Loridant, F. Bosselet, L. Burel, M. Aouine, L. Massin, P. Gelin, F. Morfin, L.Piccolo, Ultrastable iridium-ceria nanopowders synthesized in one step by solution combustion for catalytic hydrogen production, J. Mater. Chem. A 2 (2014) 1982219832.

[102] K. Tang, W. Liu, J. Li, J. Guo, J. Zhang, S. Wang, S. Niu, Y. Yang, The Effect of Exposed Facets of Ceria to the Nickel Species in Nickel-Ceria Catalysts and Their Performance in a NO + CO Reaction, ACS Appl. Mater. Interfaces 7 (2015) 26839-26849.

[103] S. Loridant, C. Feche, N. Essayem, F. Figueras, $\mathrm{WO}_{\mathrm{x}} / \mathrm{ZrO}_{2}$ Catalysts Prepared by Anionic Exchange: In Situ Raman Investigation from the Precursor Solutions to the Calcined Catalysts, J. Phys. Chem. B 2005, 109, 5631-5637.

[104] B.M. Weckhuysen, Snapshots of a working catalyst: possibilities and limitations of in situ spectroscopy in the field of heterogeneous catalysis, Chem. Commun. 2002, 97-110.

[105] M.A. Bañares, I.E. Wachs, Molecular structures of supported metal oxide catalysts under different environments, J. Raman Spectrosc. 33 (2002) 359-380.

[106] M.A. Banares, Operando methodology: combination of in situ spectroscopy and simultaneous activity measurements under catalytic reaction conditions, Catal. Today 100 (2005) 71-77.

[107] M.A. Banares, G. Mestl, Chapter 2 Structural Characterization of Operating Catalysts by Raman Spectroscopy, Adv. Catal. 52 (2009) 43-128.

[108] I.E. Wachs, C.A. Roberts, Monitoring surface metal oxide catalytic active sites with Raman Spectroscopy, Chem. Soc. Rev. 39 (2010) 5002-5017.

[109] M.O. Guerrero-Perez, M.A. Banares, Observing heterogeneous catalysts while they are working using operando Raman spectroscopy, Spectroscopy (Duluth, MN, United States) 27 (2012) 32-38.

[110] V. Calvino-Casilda, M.A. Banares, Recent advances in imaging and monitoring of heterogeneous catalysts with Raman spectroscopy, Catal. 24 (2012) 1-47.

[111] G. Mestl, M.A. Banares, Structural Characterization of Catalysts by Operando Raman Spectroscopy, in: J.A. Rodriguez, J.C. Hanson, P.J. Chupas (Eds.), In-situ Characterization of Heterogeneous Catalysts, John Wiley \& Sons, Inc., Hoboken, 2013, pp. 267-292.

[112] I.E. Wachs, M.A Banares, In situ and Operando Raman spectroscopy of oxidation catalysts, in: D. Duprez, F. Cavani (Eds.), Advanced Processes in Oxidation Catalysis: From 
Laboratory to Industry, Imperial College Press, London, 2014, pp. 420-446.

[113] G. Mestl, In situ Raman spectroscopy - a valuable tool to understand operating catalysts, J. Mol. Catal. A: Chem. 158 (2000) 45-65.

[114] A. Filtschew, C. Hess, Interpretation of Raman Spectra of Oxide Materials: The Relevance of Absorption Effects, J. Phys. Chem. C 121 (2017) 19280-19287

[115] J.-M. Jehng, G. Deo, B.M. Weckhuysen, I.E. Wachs, Effect of water vapor on the molecular structures of supported vanadium oxide catalysts at elevated temperatures, J. Mol. Catal. A: Chem. 110 (1996) 41-54.

[116] M.V. Bosco, M.A. Banares, M.V. Martinez-Huerta, A.L. Bonivardi, S.E. Collins, In situ FTIR and Raman study on the distribution and reactivity of surface vanadia species in $\mathrm{V}_{2} \mathrm{O}_{5} / \mathrm{CeO}_{2}$ catalysts, J. Mol. Catal. A: Chem., 408 (2015) 75-84.

[117] Z. Wu, A.J. Rondinone, I.N. Ivanov, S.H. Overbury, Structure of Vanadium Oxide Supported on Ceria by Multiwavelength Raman Spectroscopy, J. Phys. Chem. C 115 (2011) 25368-25378.

[118] M.V. Martinez-Huerta, J.M. Coronado, M. Fernandez-Garcia, A. Iglesias-Juez, G. Deo, J.L.G. Fierro, M.A. Banares, Nature of the vanadia-ceria interface in $\mathrm{V}^{5+} / \mathrm{CeO}_{2}$ catalysts and its relevance for the solid-state reaction toward $\mathrm{CeVO}_{4}$ and catalytic properties, J. Catal. 225 (2004) 240-248.

[119] M.V. Martinez-Huerta, G. Deo, J.L.G. Fierro, M.A. Banares, Changes in CeriaSupported Vanadium Oxide Catalysts during the Oxidative Dehydrogenation of Ethane and Temperature-Programmed Treatments, J. Phys. Chem. C 111 (2007) 18708-18714.

[120] B.M. Reddy, A. Khan, Y. Yamada, T. Kobayashi, S. Loridant, J.-C. Volta, Surface Characterization of $\mathrm{CeO}_{2} / \mathrm{SiO}_{2}$ and $\mathrm{V}_{2} \mathrm{O}_{5} / \mathrm{CeO}_{2} / \mathrm{SiO}_{2}$ Catalysts by Raman, XPS, and Other Techniques, J. Phys. Chem. B 106 (2002) 10964-10972.

[121] B.M. Reddy, A. Khan, Y. Yamada, T. Kobayashi, S. Loridant, J.-C. Volta, Structural Characterization of $\mathrm{CeO}_{2}-\mathrm{TiO}_{2}$ and $\mathrm{V}_{2} \mathrm{O}_{5} / \mathrm{CeO}_{2}-\mathrm{TiO}_{2}$ Catalysts by Raman and XPS Techniques, J. Phys. Chem. B 107 (2003) 5162-5167.

[122] B.M. Reddy, P. Lakshmanan, S., Y. Yamada, T. Kobayashi, C. Lopez-Cartes, T.C. Rojas, A. Fernandez, Structural Characterization and Oxidative Dehydrogenation Activity of $\mathrm{V}_{2} \mathrm{O}_{5} / \mathrm{Ce}_{\mathrm{x}} \mathrm{Zr}_{1-\mathrm{x}} \mathrm{O}_{2} / \mathrm{SiO}_{2}$ Catalysts, J. Phys. Chem. B 110 (2006) 9140-9147.

[123] M.V. Martinez-Huerta, G. Deo, J.L.G. Fierro, M.A. Banares, Operando Raman-GC Study on the Structure-Activity Relationships in $\mathrm{V}^{5+} / \mathrm{CeO}_{2}$ Catalyst for Ethane Oxidative Dehydrogenation: The Formation of $\mathrm{CeVO}_{4}$, J. Phys. Chem. C 112 (2008) 11441-11447.

[124] A. Iglesias-Juez, M.V. Martinez-Huerta, E. Rojas-Garcia, J.-M. Jehng, M.A. Banares, 
Nature of unusual redox cycle at vanadia ceria interface, J. Phys. Chem. C 122 (2018) 1197 1205.

[125] Z. Wu, M. Li, S.H. Overbury, Raman Spectroscopic Study of the Speciation of Vanadia Supported on Ceria Nanocrystals with Defined Surface Planes, ChemCatChem 4 (2012) 1653-1661.

[126] Y.M. Choi, H. Abernathy, H.-T. Chen, M.C. Lin, M. Liu, Characterization of $\mathrm{O}_{2}-\mathrm{CeO}_{2}$ Interactions Using in Situ Raman Spectroscopy and First-Principle Calculations, ChemPhysChem 7 (2006) 1957-1963.

[127] Y. Zhao, B.-T. Teng, X.-D. Wen, Y. Zhao, Q.-P. Chen, L.-H. Zhao,M.-F. Luo, Superoxide and Peroxide Species on $\mathrm{CeO}_{2}(111)$, and Their Oxidation Roles. J. Phys. Chem. C 116 (2012) 15986-15991.

[128] M. Huang, S. Fabris, Role of Surface Peroxo and Superoxo Species in the LowTemperature Oxygen Buffering of Ceria: Density Functional Theory Calculations, Phys. Rev. B: Condens. Matter Mater. Phys. 75 (2007) 081404.

[129] C. Schilling, M.V. Ganduglia-Pirovano, C. Hess, Christian, Experimental and Theoretical Study on the Nature of Adsorbed Oxygen Species on Shaped Ceria Nanoparticles, J. Phys. Chem. Letters 9 (2018) 6593-6598.

[130] M. Lohrenscheit, C. Hess, Direct Evidence for the Participation of Oxygen Vacancies in the Oxidation of Carbon Monoxide over Ceria-Supported Gold Catalysts by Using Operando Raman Spectroscopy, ChemCatChem 8 (2016) 523-526.

[131] C. Schilling, C. Hess, Elucidating the Role of Support Oxygen in the Water-Gas Shift Reaction over Ceria-Supported Gold Catalysts Using Operando Spectroscopy, ACS Catal. 9 (2019) 1159-1171.

[132] Ph. Colomban, G. Gouadec, Raman and IR micro-analysis of high performance polymer fibres tested in traction and compression, Composites Science and Technology 69 (2009) 10-16.

[133] Ph. Colomban, Proton and Protonic Species: The Hidden Face of Solid State Chemistry. How to Measure H-Content in Materials? Fuel Cell 13 (2013) 6-18.

[134] A. Filtschew, D. Stranz, C. Hess, Mechanism of $\mathrm{NO}_{2}$ storage in ceria studied using combined in situ Raman/FT-IR spectroscopy, Phys. Chem. Chem. Phys. 15 (2013) 90669069.

[135] A. Filtschew, C. Hess, Unravelling the mechanism of $\mathrm{NO}$ and $\mathrm{NO}_{2}$ storage in ceria: The role of defects and Ce-O surface sites, Appl. Catal. B: Environmental 237 (2018) 1066-1081. [136] P. Michalowski, A. Gräfenstein, M. Knipper, T. Plaggenborg, J. Schwenzel, J. Parisi, 
Examining Inhomogeneous Degradation of Graphite/Carbon Black Composite Electrodes in Li-Ion Batteries by Lock-In Thermography, J. Electrochem. Soc. 164 (2017) A2251-A2255.

[137] M. Toledano, R. Osorio, E. Osorio, F. Garcia-Godoy, M. Toledano-Osorio, F.S. Aguilera, Advanced zinc-doped adhesives for high performance at the resin-carious dentin interface, Journal of the Mechanical Behavior of Biomedical Materials, 62 (2016) 247-267.

[138] M.W. Zandbergen, S.D.M. Jacques, B.M. Weckhuysen, A.M. Beale, Chemical Probing within Catalyst Bodies by Diagonal Offset Raman Spectroscopy, Angew. Chem. Int. Ed. 51 (2012) $957-960$.

[139] K.D.M. Harris, Explorations in the Dynamics of Crystalline Solids and the Evolution of Crystal Formation Processes, Isr. J. Chem. 57 (2017) 154 -170.

[140] F. Tres, K. Treacher, J. Booth, L.P. Hughes, S.A.C. Wren, J.W. Aylott, J.C. Burley, Real time Raman imaging to understand dissolution performance of amorphous solid dispersions, J. Control. Release 188 (2014) 53-60.

[141] H. Kim, K.M. Kosuda, R.P. Van Duyne, P.C. Stair, Resonance Raman and surface- and tip-enhanced Raman spectroscopy methods to study solid catalysts and heterogeneous catalytic reactions, Chem. Soc. Rev. 39 (2010) 4820-4844.

[142] T. Schmid, L. Opilik, C. Blum, R. Zenobi, Nanoscale Chemical Imaging Using TipEnhanced Raman Spectroscopy: A Critical Review, Angew. Chem. Int. Ed. 52 (2013) 59405954.

[143] T. Hartman, C.S. Wondergem, N. Kumar, A. van den Berg, B.M. Weckhuysen, Surface- and Tip-Enhanced Raman Spectroscopy in Catalysis, J. Phys. Chem. Lett. 7 (2016) 1570-1584.

[144] N. Kumar, B. Stephanidis, R. Zenobi, A. J. Wain, D. Roy, Nanoscale mapping of catalytic activity using tip-enhanced Raman spectroscopy, Nanoscale, 7 (2015) 7133-7137.

[145] N.M. Ralbovsky, I.K. Lednev, Raman spectroscopy and chemometrics: A potential universal method for diagnosing cancer, Spectroc. Acta A 219 (2019) 463-487.

[146] J. Yang, J. Xu, X. Zhang, C. Wu, T. Lin, Y. Ying, Deep learning for vibrational spectral analysis: Recent progress and a practical guide, Anal. Chim. Acta 1081 (2019) 6-17.

[147] R. Deidda, P.-Y Sacre, M. Clavaud, L. Coic, H. Avohou, P. Hubert, E. Ziemons, Vibrational spectroscopy in analysis of pharmaceuticals: Critical review of innovative portable and handheld NIR and Raman spectrophotometers, Trends Anal. Chem. TrAC 114 (2019) 251-259.

[148] S.J. Mazivila, A.C. Olivieri, Chemometrics coupled to vibrational spectroscopy and spectroscopic imaging for the analysis of solid-phase pharmaceutical products: A brief review 
on non-destructive analytical methods, Trends Anal. Chem. TrAC 108 (2018) 74-87. 


\section{Caption for figures}

Figure 1. (a) Raman spectra of single crystal and nanocrystalline $\mathrm{CeO}_{2}$ together with the curve fit according to the spatial correlation model (b) Correlation length as a function of crystallite size of nanocrystalline $\mathrm{CeO}_{2}$ thin films. The dashed line is the correlation length estimated from a spherical model [28].

Figure 2. (a) Absorption spectrum and (b) UV/vis Raman spectra of ceria sample annealed at $1000{ }^{\circ} \mathrm{C}$ (crystallite size: $82.2 \mathrm{~nm}$ ). Reprinted with permission from [42] Copyright 2009 American Chemical Society.

Figure 3. Raman spectra of $\mathrm{Pt} / \mathrm{CeO}_{2}$ catalysts recorded in the $1900-2400 \mathrm{~cm}^{-1}$ spectral ranges at RT after the initial oxidizing pre-treatment at $500{ }^{\circ} \mathrm{C}$ under $20 \% \mathrm{O}_{2}$ flow for $1 \mathrm{~h}$ and after successive reductions ( $\operatorname{Red} 1,2$ and 3) at $250{ }^{\circ} \mathrm{C}$ in $\mathrm{H}_{2}-\mathrm{N}_{2}$ and re-oxidations (Reox 1, 2 and 3) at $250{ }^{\circ} \mathrm{C}$ in $\mathrm{O}_{2}-\mathrm{He}$.

Figure 4. Raman spectra of $\mathrm{CeO}_{2}$ collected at room temperature after calcination at $673 \mathrm{~K}, \mathrm{H}_{2}$ treatment at 533, 623, and $673 \mathrm{~K}$, and exposure to $\mathrm{O}_{2}$ at room temperature. The Raman peak marked with an asterisk (*) represents a laser plasma line and was used to normalize the Raman spectra intensity. Reprinted with permission from Ref. [60] Copyright 2017 American Chemical Society.

Figure 5. Raman spectra of $\mathrm{Ce}_{0.8} \mathrm{Pr}_{0.2} \mathrm{O}_{2-\delta}$ recorded after reduction at $800 \mathrm{~K}$ for 60 min under $10 \% \mathrm{H}_{2}$ flow at (a) $77 \mathrm{~K}$ and after oxidation at $800 \mathrm{~K}$ for 30 min under $5 \% \mathrm{O}_{2}$ flow (b) at 77 $\mathrm{K}$, (c) at $163 \mathrm{~K}$, and (d) at $298 \mathrm{~K}$ using $\lambda=514 \mathrm{~nm}$ and $\mathrm{P}=103 \mu \mathrm{W}$. The inset corresponds to a zoom of figures (a) and (b) between 300 and $700 \mathrm{~cm}^{-1}$ (Adapted from [72]).

Figure 6. (a) Raman spectra of (a) as-prepared and (b) calcined at $1173 \mathrm{~K} \mathrm{Ce}_{(1-\mathrm{x})} \mathrm{Zr}_{\mathrm{x}} \mathrm{O}_{2}(\mathrm{x}=0$ 0.8) samples. Reprinted with permission from Ref. [84] Copyright 2004 American Chemical Society.

Figure 7. In situ Raman spectra of (a) $2 \mathrm{wt} \% \mathrm{Pt} / \mathrm{CeO}_{2}$ calcined at $500{ }^{\circ} \mathrm{C}$ (labelled $\mathrm{Pt}(2) / \mathrm{CeO}_{2}$ 500C) and (b) $2 \mathrm{wt} \% \mathrm{Pt} / \mathrm{CeO}_{2}$ calcined at $800{ }^{\circ} \mathrm{C}$ (labelled $\mathrm{Pt}(2) / \mathrm{CeO}_{2} 800 \mathrm{C}$ ) recorded at temperature from 50 to $250{ }^{\circ} \mathrm{C}$ with a temperature step of $25^{\circ} \mathrm{C}$, under $3 \% \mathrm{H}_{2} / \mathrm{Ar}$. The 
parentheses value is the wt\% of $\mathrm{Pt}$ in the sample. Each temperature was maintained for 20 min, and Raman spectra were obtained after cooling down to $50{ }^{\circ} \mathrm{C}$. Reprinted with permission from [99] Copyright 2004 American Chemical Society.

Figure 8. Visible (A) and UV (B) Raman spectra of dehydrated $\mathrm{VO}_{\mathrm{x}} / \mathrm{r}-\mathrm{CeO}_{2}\left(\mathrm{CeO}_{2}\right.$ nanorods) and $\mathrm{VO}_{\mathrm{x}} / \mathrm{c}-\mathrm{CeO}_{2}\left(\mathrm{CeO}_{2}\right.$ nanocubes$)$ samples as a function of surface VOx density $\left(\mathrm{V} \mathrm{nm}^{-2}\right)$. The inset in parts $\mathrm{B}$ is a plot of the ratio of $\mathrm{I}_{\mathrm{D}} / \mathrm{IF}_{2 \mathrm{~g}}$ versus the surface VOx density. * indicates a plasma line from the laser. Reprinted with permission from Ref. [125] Copyright 2012 Wiley-VCH Verlag GmbH\& Co. KGaA, Weinheim.

Figure 9. Comparison of the Raman spectra of pristine $\mathrm{CeO}_{2}$ and $0.7 \% \mathrm{Pt} / \mathrm{CeO}_{2}$ catalyst after reduction at 400,450 , and $500{ }^{\circ} \mathrm{C}$ recorded at $-100{ }^{\circ} \mathrm{C}$ under $\mathrm{O}_{2}$ flow.

Figure 10. Raman spectra of bare $\mathrm{CeO}_{2}$ at $120{ }^{\circ} \mathrm{C}$ during exposure to WGS reaction conditions (left panel: $2 \% \mathrm{CO}, 8 \% \mathrm{H}_{2}{ }^{18} \mathrm{O}$, orange; right panel: $2 \% \mathrm{CO}, 8 \% \mathrm{H}_{2}{ }^{16} \mathrm{O}$, red). For comparison, spectra in argon (black), in $8 \% \mathrm{H}_{2}{ }^{18} \mathrm{O}$ (dark blue left panel), and in $8 \% \mathrm{H}_{2}{ }^{16} \mathrm{O}$ (blue right panel) are shown. Spectra are offset for clarity. Reprinted with permission from Ref. [131] Copyright 2018 American Chemical Society.

Figure 11. In situ/operando Raman spectra (phonon region) of 0.5 wt $\% \mathrm{Au} / \mathrm{CeO}_{2}$ at $120{ }^{\circ} \mathrm{C}$ exposed to argon (black), WGS reaction conditions ( $2 \% \mathrm{CO}, 8 \% \mathrm{H}_{2}{ }^{16} \mathrm{O}$, red), WGS reaction conditions ( $2 \% \mathrm{CO}, 8 \% \mathrm{H}_{2}{ }^{18} \mathrm{O}$, orange), $10 \% \mathrm{H}_{2}{ }^{16} \mathrm{O}$ (blue), $8 \% \mathrm{H}_{2}{ }^{18} \mathrm{O}$, (dark blue), $2 \% \mathrm{CO}$ (green), and $\mathrm{CO}$ oxidation reaction conditions ( $2 \% \mathrm{CO}, 10 \% \mathrm{O}_{2}$, brown). Prior to all in situ measurements, the catalyst was equilibrated in argon at $120{ }^{\circ} \mathrm{C}$. The $\mathrm{F} 2 \mathrm{~g}$ band is cut off, and the position of the $\mathrm{F}_{2 \mathrm{~g}}$ band is given at the right of the panel. Spectra are offset for clarity. Reprinted with permission from Ref. [131] Copyright 2018 American Chemical Society.

Figure 12. (a) In situ Raman spectra of oxidatively treated ceria showing the temporal evolution upon exposure to $500 \mathrm{ppm} \mathrm{NO}_{2} / 20 \% \quad \mathrm{O}_{2} / \mathrm{N}_{2}$ at $30{ }^{\circ} \mathrm{C}$ An enlarged view of the Raman spectra is shown for the regions (b) $200-700 \mathrm{~cm}^{-1}$, (c) $500-1800 \mathrm{~cm}^{-1}$, and (d) 3000 $4000 \mathrm{~cm}^{-1}$. Reprinted with permission from Ref. [135] Copyright 2018 Elsevier B.V. All rights reserved. 